\title{
o7. Türk film adlarına derlem tabanlı bir bakış
}

Ferdi BOZKURT

APA: Bozkurt, F. (2021). Türk film adlarına derlem tabanlı bir bakış. RumeliDE Dil ve Edebiyat Araştırmaları Dergisi, (24), 93-127. DOI: 10.29000/rumelide.995421.

$\ddot{\mathbf{O} z}$

Bugün dünyada kendine ait sineması olmayan hemen hemen hiçbir toplum kalmamıştır. Bir sektör hâline gelmiş film dünyası artık sanayileşmiş ve dünyadaki hemen her türden insana ulaşmış durumdadır. Kökeni edebiyata dayanan filmlerin, kendilerine has adları vardır. Bu çalışmanın amacı, insanın sanatsal yaratıcılı̆̆ını ortaya çıkaran filmlerin önemli bir parçası durumundaki adlarının derlem tabanlı bir analizini yapmak, türlerine göre benzerlik ve farklılık gösteren yönlerini tespit etmektir. Adbilim alan yazın taraması sonucunda film adlarının bir dil malzemesi olarak kullanılması hususunda özellikle İngilizce için çeşitli çalışmalar olduğu görülmüştür. Öte yandan Türkiye’de bu tür çalışmalara tesadüf edilememesi çalışmanın güçlü yönünü oluşturmuştur. Veri tespitinden sonra verinin büyüklüğü fark edilip nitelikli bir raporlamaya ulaşabilmek amacıyla yaklaşık 20.000 birimlik, küçük çapta, Türk Film Adları Derlemi adında bir derlem oluşturulmuştur. Bu derlem içindeki film adları el ile çeşitli işaretlemelere tabi tutulmuştur. Veri seçiminde bir evren içinden bir örneklem kesiti üzerinde çalışmak yerine Türk sinemasındaki tüm film adları tercih edilmiştir. Bu veri tabanı 1917 ve 2020 yılları arasını kapsamaktadır. Bu veri tabanında 15 tür, 7923 adet film vardır. Çalışma sonucunda türlerin özelliklerini yansıtan çeşitli veriler elde edilmiştir.

Anahtar kelimeler: Film adları, Türk sineması, derlem, sıklık, derlem tabanlı

\section{A corpus-based view of Turkish movie names}

\begin{abstract}
There is almost no society left in the world today that does not have its own cinema. The film world, which has became a immense sector, has now industrialized and has reached almost all kinds of people in the world. The films whose origins are based on literature have their own names. The aim of the current study is to make a corpus-based analysis of the names, which are an important part of the films that reveal the artistic creativity of human beings, and to determine their similarities and differences according to their genres. There are various studies on the use of movie titles as a language material has been encountered as a result of the onomatics literature review. On the other hand, the fact that such studies were not encountered in Turkey constituted the strength of the study. The Turkish Film Names Corpus which contains 20,000 tokens was built in order to realize a qualified report.Various grammatic details manually marked in this database. All movie names in Turkish cinema were preferred instead of working on a sampled data. This database covers the years between 1917 and 2020. In this database, there are 15 genres, 7923 films. Various data reflecting the characteristics of the species were obtained as a result of the study,
\end{abstract}

Keywords: Movie names, Turkish movie, corpus, frequency, corpus-based

Dr. Öğr. Üyesi, Anadolu Üniversitesi, Açköğretim Fakültesi, Türk Dili ve Edebiyatı Bölümü, Yeni Türk Dili ABD (Eskişehir, Türkiye), ferdib@anadolu.edu.tr, ORCID ID: 00oo-0002-2209-8673 [Araştırma makalesi, Makale kayıt tarihi: 11.05.2021-kabul tarihi: 20.09.2021; DOI: 10.2900o/rumelide.995421

Adres Address

RumeliDE Dil ve Edebiyat Araştırmaları Dergisi $\quad$ RumeliDE Journal of Language and Literature Studies Osmanağa Mahallesi, Mürver Çiçeği Sokak, No:14/8 Osmanağa Mahallesi, Mürver Çiçeği Sokak, No:14/8

Kadıköy - İSTANBUL / TÜRKIYE 34714 Kadıköy - ISTANBUL / TURKEY 34714 e-posta: editor@rumelide.com $\quad$ e-mail: editor@rumelide.com, tel: +90 $5057958124,+90216773$ o 616 phone: +90 505 7958124, +90 216773 o 616 


\section{o. Giris}

Türkçeye Fransızcadan giren sinema "cinéma” Türk Dil Kurumu Güncel Türkçe Sözlük’te² "Güzel sanatların dalı olarak yansıtılmaya uygun olan filmleri gerçekleştirme ve yaratma sanatı, beyaz perde, yedinci sanat." ve "Herhangi bir hareketi düzenli aralıklarla parçalara bölerek bunların resimlerini belirleme ve sonra bunları gösterici yardımıyla karanlık bir yerde, bir ekran veya perde üzerinde yansıtarak hareketi yeniden oluşturma işi.” biçiminde tanımlanmaktadır. Bugün hemen her ülkeye ait bir sinema tarihi vardır. Türkiye'de ise ilk Türk filmi olarak Fuat Uzkınay’ın "Ayastefanos Abidesinin Yıkılışı" adlı filmi sayılmaktadır (Evren, 1995, s.94).

Günümüzde sinema, dünyada milyonlarca çalışanı olan bir endüstri hâline gelmiştir. Neredeyse en yaygın iletişim aracı olan televizyon, sinema ya da internet yoluyla yılda belki de bir kitabın dahi giremediği kimi evlere onlarca belki de yüzlerce sinema filmi girmektedir.

Dil araştırmalarında edebî dil, konuşma dili gibi unsurlar genellikle dil malzemesi olarak ele alınarak çeşitli çalışmalar yapılmaktadır. Sinemanın çıkış noktasını teşkil eden tiyatro ne kadar edebî bir alansa sinema ve dolayısıyla filmler de birer edebî ürün özelliği taşımaktadırlar. Sinemadaki dil, bir dil malzemesi olarak kullanılabileceği gibi film adlarını da bir dil malzemesi olarak incelemek mümkündür. Bir film senaryosu sanatsal yeteneğin dışa vurumu olduğu gibi bir filmin belki de en önemli parçalarından biri olan filmin adı da insan yaratıcılığının dışavurumudur.

\section{Kuramsal artalan}

\subsection{Adbilim}

Dilbilimin adlar üzerinde çalışan dalına adbilim "onomastics" adı verilmektedir. Adbilim, her ne kadar başlangıçta "kişi adları" ve "yer adları"nı inceleyen bir bilim dalı olarak tanınmış ve gelişmeye başlamış olsa da günümüzde artık çok daha geniş bir çerçevede tanımlanmakta, her türlü ad, bu alan içerisinde araştırılmaktadır (Şahin, 2015: s.17).

Tablo 1: Özel adların türleri3 (Hough, 2020)

Tür

Kişilerin adları

Yerlerin adları

Arazi şekillerinin adları

Yapıların adları

Güzergâhların adları

Hayvanların adları

Etnik ve sosyal grupların adları

Olayların adları

Gökbilimsel nesnelerin adları
Alt Tür

kişi adları, aile adları, soyadları, takma adlar

ülkeler, bölgeler, şehirler, kasabalar, köyler

denizler, nehirler, dereler, göller, dağlar, tepeler, vadiler, ormanlar, korular, bataklıklar

evler, kiliseler, barlar, okullar, hava alanları, oteller, tren istasyonları

yollar, caddeler, patikalar, pistler, köprüler, ırmak geçitleri, kanallar, nakliye yolları

evcil hayvanlar, tazılar, yarış atları, inekler

milletler, kabileler, siyasi partiler, kulüpler, spor takımları

yarışmalar, fuarlar, yarışlar

gezegenler, yldızlar

Türk Dil Kurumu Güncel Türkçe Sözlük https://sozluk.gov.tr/ (Erişim tarihi: 11.12.2020)

Hough'dan (2020) hareketle tablolaştırılmıştır.

RumeliDE Dil ve Edebiyat Araşturmaları Dergisi Osmanağa Mahallesi, Mürver Çiçeği Sokak, No:14/8 Kadıköy - ÍSTANBUL / TÜRKIYE 34714 e-posta: editor@rumelide.com tel: +90 505 7958124, +90 2167730616
Address

RumeliDE Journal of Language and Literature Studies Osmanağa Mahallesi, Mürver Çiçeği Sokak, No:14/8

Kadıköy - ISTANBUL / TURKEY 34714

e-mail: editor@rumelide.com,

phone: +90 505 7958124, +90 2167730616 

Araçların adları
uçaklar, lokomotifler, gemiler
Ticari ürünlerin adları
çikolatalar, rujlar, şaraplar
Yaratıcı çalışmaların adları
kitaplar, filmler, oyunlar, şiirler

Adbilim çeşitli ad türlerini çalışabilmektedir. Tablo 1.de özel adların türleri gösterilmiştir.

Uzunca sıralanmış liste incelendiğinde türlerin oldukça kapsamlı olduğu göze çarpmaktadır. Türkiye'de adbilim alanında yapılmış çalışmalara göz atıldığında kişi ve yer adları ile ilgili yapılan çalışmaların sayı bakımından adbilimin diğer çalışma konularına göre baskın biçimde fazla olduğu görülmektedir. 4

Adbilimin ele alabileceği zengin konu çeşitliliği görüldüğünde Türkiye'de adbilimle çalışması yapılabilecek çeşitli veri setlerinin varlı̆̆ı dikkat çekmektedir. İngilizce alan yazın tarandığında değişik türden, ilginç adlarla ilgili adbilim çalışmalarına rastlamak mümkündür. Örneğin Evans (1967) Amerika'daki kurşun kalem adlarıla ilgili, Nuessel (2010) enerji içeceklerinin marka adlarıyla ilgili, Nuessel (2014) banyo tuzlarının adları, Nuessel (2016) elektronik sigara adlarıla ilgili adbilim çalışmaları yapılmıştır. Hough'un (2020) listesindeki adbilim türleri ile Türkçe yapılan çalışmalar karşılaştırıldığında Türkçedeki siyasi parti adları, yarış atları, uçak adları, içecek adları, şarkı adları gibi birçok konuda henüz akademik anlamda çalışma yapılmadığı dikkat çekmektedir.

\subsection{Eser adları, film adları}

Hough (2020), sınıflandırmasında yaratıcı çalışmaların adlarının türlerini "kitaplar", "filmler", "oyunlar", "şiirler" biçiminde sıralamıştır. hrema (Yunanca) "eşya, nesne, ürün, eser" + onima "ad" sözcüklerinin birleşmesinden oluşan hrematonim terimi, "eşya adı, eser adı" anlamına gelmektedir. Hrematonimi "eseradbilim” de şairler, yazarlar tarafından yazılan roman, hikâye, şiir kitabı gibi edebî ürünlere, tablolara, sanatçıların kullanmış oldukları eşyalara verilen adları ve bu adlandırmalara benzeyen daha pek çok adlandırmayı araştırıp inceleyen, onların anlamlarını, adlandırmalardaki benzerlikleri ve farklılıkları inceleyen adbilim dalıdır (Şahin, 2015: s.58).

İngilizce alan yazında yazınsal adbilim ile yapılıış birçok çalışma bulunmaktadır. Özellikle roman, öykü adları, roman ve öykülerdeki karakterlerin adları ya da eserlerde geçen yer adları ile ilgili geniş bir alan yazın bulunmaktadır (Nicolaisen, 2008; Alvarez-Altman, 1981;Alvarez-Altman vd., 1987; Smith, 2016). Özellikle Shakespeare gibi ünlü yazarların çalışmalarını konu alan o kadar yazınsal adbilim çalışması mevcuttur ki sadece bu konuyu kapsayan bibliyografik çalışmalar (Rajec, 1987) dahi yapılmıştır. Hatta sadece yazınsal adbilim konusundaki makaleleri 1974-1989 yılları arasında "Literary Onomastics Studies" adıyla sonra da "Journal of Literary Onomastics" adıyla yayımlanmış bir bilimsel hakemli dergi bile bulunmaktadır. Bu çalışmaların, Türk edebiyatçlları için benzerleri (Demir, 2019; Bulut, 2020) yapılmakla birlikte nicelik bakımından yabancı alan yazınla eşit değildir.

\section{3. Öncül çalışmalar}

Türkiye'de eser adları ile ilgili çalışmaların sayısı da çok fazla değildir. Doğrudan bir kitabın ya da eserin adına yönelik çalışmaların (Coşkun, 1981; Gülensoy, 1987; Karamanlığlu, 1970) sayısı azdır, birden çok eser adının veri tabanı olarak kullanıldığı çalışmalar da sayıca pek fazla değildir. Bu çalışmaların

4 Bu bibliyografik çalıșmalar (Keleş, 1996; Sakaoğlu, 2001; Kibar, 2005; Kayasandık, 2019) incelendiğinde kiși ve yer adları ile ilgili yapılmış bildiri, makale, lisansüstü tez, kitap düzeyindeki çalışmaların sayıca diğer konularla ilgili yapılmış çalışmaların sayısına göre yüksek olduğu net biçimde görülmektedir.

Adres Address

RumeliDE Dil ve Edebiyat Araşttrmaları Dergisi $\quad$ RumeliDE Journal of Language and Literature Studies

Osmanağa Mahallesi, Mürver Çiçeği Sokak, No:14/8 Osmanağa Mahallesi, Mürver Çiçeği Sokak, No:14/8

Kadıköy - İSTANBUL / TÜRKIYE 34714 Kadıköy - ISTANBUL / TURKEY 34714

e-posta: editor@rumelide.com $\quad$ e-mail: editor@rumelide.com,

tel: +90 $5057958124,+90216773$ o 616 phone: +90 505 7958124, +90 216773 o 616 
kapsamları ve kısaca içerikleri şöyledir: Karademir (2009) tesadüfî örnekleme yöntemiyle seçtiği beş yüz elli çocuk kitabının adlarındaki dilbilgisel özellikleri ele almış, çalışmanın devamı niteliğindeki bir sonraki çalışmasında (Karademir, 2010) önceki çalışma için seçtiği 550 çocuk kitabının adlarını edebî özellikleri bakımından incelemiştir. Özer (2015), lisansüstü tez düzeyindeki çalışmasında ise 2011 ylı itibariyle En Çok Kazanan Yazarlar olarak kabul edilen 16 yazarın 138 eserinin adı ile ilgili yapısal ve kavramsal analiz yapmıştır.

Kızanbek (2019) Tanzimat Dönemi'nden 2018 yılları arasındaki 3541 adet Türk roman adını üslup ve söz dizimi yönleriyle incelemiştir.

Orbay (2019) çalışmasında 1890-1990 yılları arasındaki yüz yıllık dönemde, öykü türünde eser vermiş 103 yazarın 658 öykü kitabı adını söz dizimsel özelliklerine göre incelemiştir.

Yaratıcı çalışmaların adlarının diğer bir türü olup hem özellikleri hem de veriliş biçimleri açısından roman, hikâye adlarına benzeyen ve bu çalışmanın asıl konusu olan film adları ile İngilizce olarak yapılmış bazı çalışmalar vardır.

Bernstein (2007) 1914 ve 2006 yılları arasında adında (başlı̆̆ında) New York şehri ile bu şehre ait yer adlarının geçtiği 396 film adı ile ilgili bir çalışma yapmıştır.

Dengler (1975) çalışmasında 1900 ve 1968 yılları arasındaki 7.590 Amerikan film adını Genel Sorgu Sistemi (General Inquirer System) adlı bilgisayar programı ile sözcüklerin kendi aralarındaki dilsel ilişkilerine göre kodlamıştır. Bu çalışma, bugünkü derlem tabanlı dil araştırmalarının ortaya koyabildiği veri zenginliği ile kıyaslanamasa da tarihi itibariyle adbilim çalışmalarında ilk kez bilgisayar tabanlı yaklaşımlardan biri olması nedeniyle önem arz etmektedir.

Frey vd.nin (1981) film adları ile ilgili çalışması odaklandığı amaç itibariyle ilginç bir çalışmadır. Çalışmada, toplumbilimci David Riesman'ın "Yalnız Kalabalık: Amerikan Toplumsal Karakterinin Değişimi Üzerine Bir İnceleme” adlı eserindeki Amerikan toplumsal karakterlerinin iç ve dış yönelimli değişimi tezini test etmek için 2840 film adının bilgisayarlı bağlamsal analizi yapılmıştır.

Tarpley (1985) 16.500 film adını incelemiş, bu filmlerin adlarında geçen yer adlarıly ilgili istatistiksel bir çalışma yaparak film adlarındaki yer adlarının sıklığını ve sıralamasını elde etmiştir.

Akademik alan yazın incelendiğinde, Türk sinemasındaki film adlarının söz varlığı ile ilgili herhangi bir akademik çalışmaya rastlanılmamıştır. Bu açıdan bu çalışma alanında ilk olması ve gelecek çalışmalara bir hareket noktası olabilmesi açısından önem taşımaktadır.

\section{2. Çalışmanın amacı}

$\mathrm{Bu}$ çalışmanın amacı, insanın sanatsal yaratıcılığını ortaya çıaran filmlerin önemli bir parçası durumundaki Türk film adlarının derlem tabanlı bir analizini yapmak, türlerine göre benzerlik ve farklılık gösteren yönlerini tespit etmektir.

\section{Araştırma soruları}

Türk film adlarının sözcüksel dağılımı nasıl bir özelliktedir?

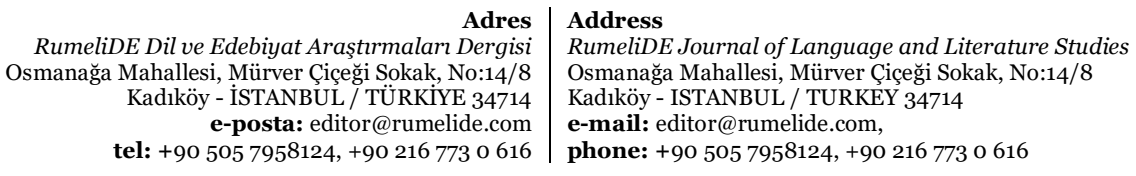


Türk film adları ile film türleri arasında bir ilişki var mıdır?

Türk film adları nasıl bir söz varlığına sahiptir?

\section{Veri ve yöntem}

\subsection{Veri setinin belirlenmesi}

Öncelikle Türk sinemasındaki film adlarının elde edilebileceği bir kaynak tespit edilmeye çalışılmıştır. Sinema alanında film adlarının bir arada bulunduğu en kapsamlı eser olarak Agah Özgüç̧ün hazırladığı eserler $(1998,2009,2012)$ tespit edilmiştir. Bu eserler oldukça kapsamlı olmakla birlikte yayın yılından dolayı 2012 yllı sonrasında çekilmiş filmleri içermemektedir. Bu çalışmada Türk film adlarının tamamına ulaşmak ve dolayısıyla çalışmanın güncel film adlarını da içermesi amaçlandığı için kaynak taraması genişletilmiştir. Tarama sırasında Bilim ve Sanat Vakfı tarafından hazırlanan Türk Sineması Araştırmaları (TSA) projesi kapsamında oluşturulan www.tsa.gov.tr adlı genel ağ sitesine rastlanmıştır. Bu proje hem Agah Özgüç'ün çalışmalarını içermesi hem güncel film adlarını içermesi bakımından önemli bir çalışmadır. Ancak bu genel ağ sitesinde bazı filmlere ait tür, yıl gibi bilgilerde eksiklik olduğu için www.sinemalar.com gibi genel ağ sitelerinden de çeşitli bilgiler elde edilmiştir.

Nihayetinde bu çalışmanın veri tabanını Agah Özgüç’ün sözü geçen eserlerindeki, TSA genel ağ sitesi ve https://www.sinemalar.com sitesindeki film adları oluşturmuştur.

\subsection{Veri tabanının kapsamının belirlenmesi}

Yukarıda bahsedilen kaynaklarda gerçeklik bakımından belge film, belgesel, deneysel, kurmaca; metraj bakımından uzun ve kısa metraj filmler olduğu tespit edilmiştir. Çalışmada türlere göre söz varlığı değişkenliğini incelemek amaçlandığı için dolayısıyla sinemanın doğası gereği belgesel, deneysel, belge filmlerin dram, komedi, erotik, melodram gibi alt türleri olmadığı için bu tür filmler veri tabanının dışında tutulmuştur. Yukarıda bahsedilen türlerin tamamı ayrılmaksızın toplamda 8348 film tespit edilmiştir. Bu verilerin arasında çalışmanın ana konusunu tarih bakımından 1917-2020 yılları arası; metraj bakımından uzun metraj; gerçeklik bakımından kurmaca türündeki filmler oluşturmuştur. Bu sinırlama ile film sayısı 7923 ’tür.

\subsection{Verilerin özellikleri}

Tablo 2: Türlerin sayları

$\begin{array}{llll}\text { Sira } & \text { Tür Adı } & \text { Sayı } & \% \\ 1 & \text { Aksiyon } & 345 & 4,35 \\ 2 & \text { Animasyon } & 18 & 0,23 \\ 3 & \text { Belgesel } & 19 & 0,24 \\ 4 & \text { Bilimkurgu } & 8 & 0,10 \\ 5 & \text { Döküdrama } & 2 & 0,03 \\ 6 & \text { Dram } & 3097 & 39,09 \\ 7 & \text { Erotik } & 85 & 1,07 \\ 8 & \text { Fantastik } & 92 & 1,16 \\ 9 & \text { Gerilim } & 53 & 0,67\end{array}$

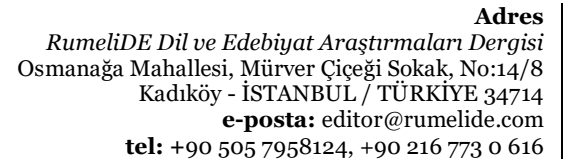

Address

RumeliDE Journal of Language and Literature Studies

Osmanağa Mahallesi, Mürver Çiçeği Sokak, No:14/8

Kadıköy - ISTANBUL / TURKEY 34714

e-mail: editor@rumelide.com tel: +90 505 7958124, +90 2167730616 phone: +90 505 7958124, +902167730616 


$\begin{array}{llll}10 & \text { Komedi } & 1409 & 17,78 \\ 11 & \text { Korku } & 185 & 2,33 \\ 12 & \text { Macera } & 770 & 9,72 \\ 13 & \text { Melodram } & 1797 & 22,68 \\ 14 & \text { Müzikal } & 3 & 0,04 \\ 15 & \text { Western } & 40 & 0,50 \\ \text { Toplam } & & \mathbf{7 9 2 3} & \mathbf{\% 1 0 0}\end{array}$

Tablo 2.de veri tabanını oluşturan filmlerin türlere göre dağılımı gösterilmiştir. Buna göre Türk sinemasının yaklaşık 100 ylllı sürecinde en fazla ortaya konulan türler dram, melodram ve komedidir. Bu üç türün toplam sayısı (6303) neredeyse toplam film sayısına yaklaşmaktadır. Dolayısıyla bu üç türü Türk sinemasının ana türleri olarak saymak doğru olacaktır.

Tablo 3: Yıllara göre film sayıları

\begin{tabular}{|c|c|c|c|c|c|c|c|c|c|c|c|}
\hline Yll & Sayı & $\%$ & Yil & Sayı & $\%$ & Yll & Sayı & $\%$ & Yil & Sayı & $\%$ \\
\hline 1917 & 3 & 0,04 & 1946 & 6 & 0,08 & 1971 & 267 & 3,37 & 1996 & 49 & 0,62 \\
\hline 1918 & 1 & 0,01 & 1947 & 11 & 0,14 & 1972 & 299 & 3,77 & 1997 & 30 & 0,38 \\
\hline 1919 & 5 & 0,06 & 1948 & 18 & 0,23 & 1973 & 214 & 2,70 & 1998 & 27 & 0,34 \\
\hline 1920 & 2 & 0,03 & 1949 & 19 & 0,24 & 1974 & 186 & 2,35 & 1999 & 25 & 0,32 \\
\hline 1921 & 2 & 0,03 & 1950 & 23 & 0,29 & 1975 & 228 & 2,88 & 2000 & 32 & 0,40 \\
\hline 1922 & 2 & 0,03 & 1951 & 33 & 0,42 & 1976 & 164 & 2,07 & 2001 & 26 & 0,33 \\
\hline 1923 & 3 & 0,04 & 1952 & 58 & 0,73 & 1977 & 131 & 1,65 & 2002 & 20 & 0,25 \\
\hline 1924 & 1 & 0,01 & 1953 & 44 & 0,56 & 1978 & 129 & 1,63 & 2003 & 29 & 0,37 \\
\hline 1925 & 1 & 0,01 & 1954 & 51 & 0,64 & 1979 & 199 & 2,51 & 2004 & 35 & 0,44 \\
\hline 1927 & 1 & 0,01 & 1955 & 61 & 0,77 & 1980 & 67 & 0,85 & 2005 & 32 & 0,40 \\
\hline 1928 & 2 & 0,03 & 1956 & 53 & 0,67 & 1981 & 69 & 0,87 & 2006 & 46 & 0,58 \\
\hline 1929 & 2 & 0,03 & 1957 & 59 & 0,74 & 1982 & 75 & 0,95 & 2007 & 55 & 0,69 \\
\hline 1931 & 1 & 0,01 & 1958 & 85 & 1,07 & 1983 & 80 & 1,01 & 2008 & 68 & 0,86 \\
\hline 1932 & 1 & 0,01 & 1959 & 80 & 1,01 & 1984 & 127 & 1,60 & 2009 & 86 & 1,09 \\
\hline 1933 & 7 & 0,09 & 1960 & 92 & 1,16 & 1985 & 133 & 1,68 & 2010 & 66 & 0,83 \\
\hline 1934 & 3 & 0,04 & 1961 & 121 & 1,53 & 1986 & 212 & 2,68 & 2011 & 99 & 1,25 \\
\hline 1937 & 1 & 0,01 & 1962 & 137 & 1,73 & 1987 & 211 & 2,66 & 2012 & 104 & 1,31 \\
\hline 1938 & 2 & 0,03 & 1963 & 119 & 1,50 & 1988 & 122 & 1,54 & 2013 & 92 & 1,16 \\
\hline 1939 & 4 & 0,05 & 1964 & 174 & 2,20 & 1989 & 98 & 1,24 & 2014 & 148 & 1,87 \\
\hline 1940 & 4 & 0,05 & 1965 & 215 & 2,71 & 1990 & 90 & 1,14 & 2015 & 157 & 1,98 \\
\hline 1941 & 2 & 0,03 & 1966 & 244 & 3,08 & 1991 & 43 & 0,54 & 2016 & 174 & 2,20 \\
\hline 1942 & 4 & 0,05 & 1967 & 210 & 2,65 & 1992 & 42 & 0,53 & 2017 & 161 & 2,03 \\
\hline 1943 & 2 & 0,03 & 1968 & 180 & 2,27 & 1993 & 86 & 1,09 & 2018 & 179 & 2,26 \\
\hline 1944 & 4 & 0,05 & 1969 & 233 & 2,94 & 1994 & 85 & 1,07 & 2019 & 114 & 1,44 \\
\hline 1945 & 2 & 0,03 & 1970 & 230 & 2,90 & 1995 & 36 & 0,45 & 2020 & 58 & 0,73 \\
\hline
\end{tabular}

\footnotetext{
Adres | Address

RumeliDE Dil ve Edebiyat Araştırmaları Dergisi $\quad$ RumeliDE Journal of Language and Literature Studies Osmanağa Mahallesi, Mürver Çiçeği Sokak, No:14/8 $\quad$ Osmanağa Mahallesi, Mürver Çiçeği Sokak, No:14/8 Kadıköy - ÍSTANBUL / TÜRKIYE 34714 Kadıköy - ISTANBUL / TURKEY 34714 e-posta: editor@rumelide.com e-mail: editor@rumelide.com, tel: +90 505 7958124, +90 2167730616 phone: +90 505 7958124, +90 2167730616
} 
Tablo 3.te yıllara göre film sayıları gösterilmiştir. En çok filmin yapıldığı ilk on yıl sırasıyla şöyledir: 1972 (299), 1971 (267), 1966 (244), 1969 (233), 1970 (230), 1975 (228), 1965 (215), 1973 (214), 1986 (212), 1987 (211). Tablo incelendiğinde özellikle 1960'lı yıllarda ve 1980'li ylllarda film sayısının oransal olarak yüksek olduğu görülmektedir.

\subsection{Veri tabanının tasarımı}

Başlangıç için yapılan sınırlandırmadaki veri büyüklüğü hesabı ile yaklaşık 25 bin sözcüklük bir dil verisi ortaya çıacağı öngörülmüştür. Böyle bir verinin işlenebilmesi ve çalışmanın araştırma soruları kapsamında raporlanabilmesi için küçük bir derlem oluşturulması gerekmiştir. Zira film türlerinin adlara göre değişkenliğinin ve benzerliğinin görülebilmesi için derlemin daha sağlıklı raporlama sunacağı öngörülmüştür.

\subsection{Türk film adları derleminin etiketlendirilmesi ve oluşturulması}

Öncelikle film adlarındaki kesme, virgül, noktalı virgül, iki nokta gibi işaretler temizlenmiştir. Sözcüklerin her biri eylem soylu sözcükler (eylemler) ve ad soylu sözcükler (ad, önad, belirteç, bağlaç, ilgeç, adıl, ünlem) biçiminde iki ana ulam çerçevesinde gövdelenmiştir.

Gövdeleme sırasında özellikle eş yazımlılıktan kaynaklanabilecek anlamsal farklılıklara dikkat edilmiştir. Örneğin "Sevgi Taşı (2013)" filmindeki "taşı" sözcüğünün "Kimyasal veya fiziksel durumu değişiklikler gösteren, rengini içindeki maden, tuz ve oksitlerden alan sert ve katı madde" anlamında mı, "Bir şeyi bir yerden alıp başka bir yere götürmek" anlamında mı olduğunu tespit etmek için filmlerin konusu ve içeriği de incelenmiştir.

Gövdeleme (lemmatization) sırasında yazımsal farklılıklara dikkat edilmiştir. Örneğin "Kanal-i-zasyon" biçiminde yazılan sözcüğü kanalizasyon olarak kabul edilmiş, konuşma dili gibi yazılan "N'apcaz Şimdi? (2012)" film adı, "ne”, “yapacağız", "şimdi” biçiminde üç sözcük olarak hesaplanmıştır. İşaretlenen veriler Anthony (2020) tarafından hazırlanmış AntConc (Versiyon 3.5.9) yazılımında işlenmiştir.

\section{Bulgular ve yorum}

Etiketleme sırasında Türk sinemasında bazı film adlarının birebir biçimde kullanıldığı dikkat çekmiştir. Bu çalışmanın veri setini oluşturan 7923 film adının 695 tanesi birebir aynı biçimde kullanılmıştır. Veri tabanındaki 7228 filmin adı benzersizdir. 5 film adı 5 kere, 16 film adı 4 kere, 89 film adı 3 kere, 451 film adı 2 kere, 6665 filmin adı 1 kere aynı biçimde kullanılmıştır. 5

Adları birebir aynı olup en çok tekrar eden film adlarından örnekler ve sayıları şöyledir: İlk Aşk (5), Kaçak (5), Kader (5), Sürgün (5), Yabancı (5), Acı (4), Aşkların En Güzeli (4), Ayrılık (4), Baş Belası (4), Batak (4), Damga (4), Ferhat ile Şirin (4), Keloğlan (4), Misafir (4), Seni Seviyorum (4), Sürtük (4), Tuzak (4), Uçurum (4), Yara (4), Yasak Aşk (4), Zehirli Çiçek (4), Acı Günler (3), Acı Sevda (3), Afacan (3), Ali (3), Altın Kafes (3), Arzu (3), Avare (3), Ayrı Dünyalar (3), Azap (3), Bekçi (3), Beni Mahvettiler (3), Berduş (3), Bırakın Yaşayalım (3), Büyük Günah (3).

Öte yandan bazı filmlerin de devam filmi niteliğinde olduğu ve bu filmlerin adlarında bazı sözcüklerin aynen tekrar ettiği görülmektedir. Dolayısıyla bu filmlerde geçen bazı sözcükler birden çok kez veri

Tekrarlı film adları veri havuzuna geçtikleri sayı kadar eklenmiştir.

Adres

RumeliDE Dil ve Edebiyat Araşttrmaları Dergisi $\quad$ RumeliDE Journal of Language and Literature Studies Osmanăga Mahallesi, Mürver Ciçeği Sokak, No:14/8 $\quad$ Osmanağa Mahallesi, Mürver Çiçeği Sokak, No:14/8 Kadıköy - İSTANBUL / TÜRKIYE 34714 Kadıköy - ISTANBUL / TURKEY 34714 e-posta: editor@rumelide.com e-mail: editor@rumelide.com, tel: +90 505 7958124, +90 216773 o 616 phone: +90 505 7958124, +90 2167730616 
tabanına girmiştir. Toplam 172 film, devam niteliğindedir. Devam filmi niteliğinde; 1 tane 16 ayrı filmden, 1 tane 10 filmden, 3 tane 6 ayrı filmden, 2 tane 5 ayrı filmden, 2 tane 4 ayrı filmden, 8 tane 3 ayrı filmden, 48 tane 2 ayrı filmden oluşan devam filmi vardır. Devam filmleri dram, komedi, macera ve melodram türündedir.

TFAD (Türk Film Adları Derlemi)'daki en fazla sayıda devamı olan filmlerinden bazıları şöyledir:

Cilalı İbo 16 film: Cilalı İbo Avrupa'da, Cilalı İbo Beni Anneme Götür, Cilalı İbo Casuslar Arasında, Cilalı İbo İstanbul Kaldırımlarında, Cilalı İbo Kadın Avcısı, Cilalı İbo Kızlar Pansiyonunda, Cilalı İbo Maceralar Peşinde, Cilalı İbo Perili Köşkte, Cilalı İbo Rüyalar Aleminde, Cilalı İbo Teksas Fatihi, Cilalı İbo ve Kırk Haramiler, Cilalı İbo ve Tophane Gülü, Cilalı İbo Yetimler Meleği, Cilalı İbo Yıldızlar Arasında, Cilalı İbo Zoraki Baba, Cilalı İbo'nun Çilesi.

Hababam Sınıfı 10 film: Hababam Sınıfı: İnek Şaban'ın Maceraları, Hababam Sinıfı Sınıfta Kaldı İnek Şaban, Hababam Sınıfı Uyanıyor, Hababam Sinıfı Tatilde, Hababam Sinıfı Dokuz Doğuruyor, Hababam Sınıfı Güle Güle, Hababam Sinıfı Askerde, Hababam Sınıfı Merhaba, Hababam Sinıfı 3,5, Hababam Sinıfi Yeniden.

Dabbe 6 film: Dabbe (D@bbe), DAbbe (D@bbe) Bir Cin Vakası, Dabbe (D@bbe) Cin Çarpması, Dabbe 2 (D@bbe 2), Dabbe (D@bbe) Zehr-i Cin, Dabbe (Dab6e).

Recep İvedik 6 film: Recep İvedik, Recep İvedik 2, Recep İvedik 3, Recep İvedik 4, Recep İvedik 5, Recep İvedik 6.

Siccîn 6 film: Siccîn "Büyü Haramdır”, Siccîn 2: Her Canlı Ölümü Tadacaktır, Siccîn 3: Cürmü Aşk, Siccîn 4, Siccîn 5, Siccîn 6.

Çakallarla Dans 5 film: Çakallarla Dans, Çakallarla Dans 2 Hastasıyız Dede, Çakallarla Dans 3 Sıfır Sıkıntı, Çakallarla Dans 4, Çakallarla Dans 5.

\subsection{Sözcük sayıları}

Tablo 4: Film türlerine göre sözcük sayıları

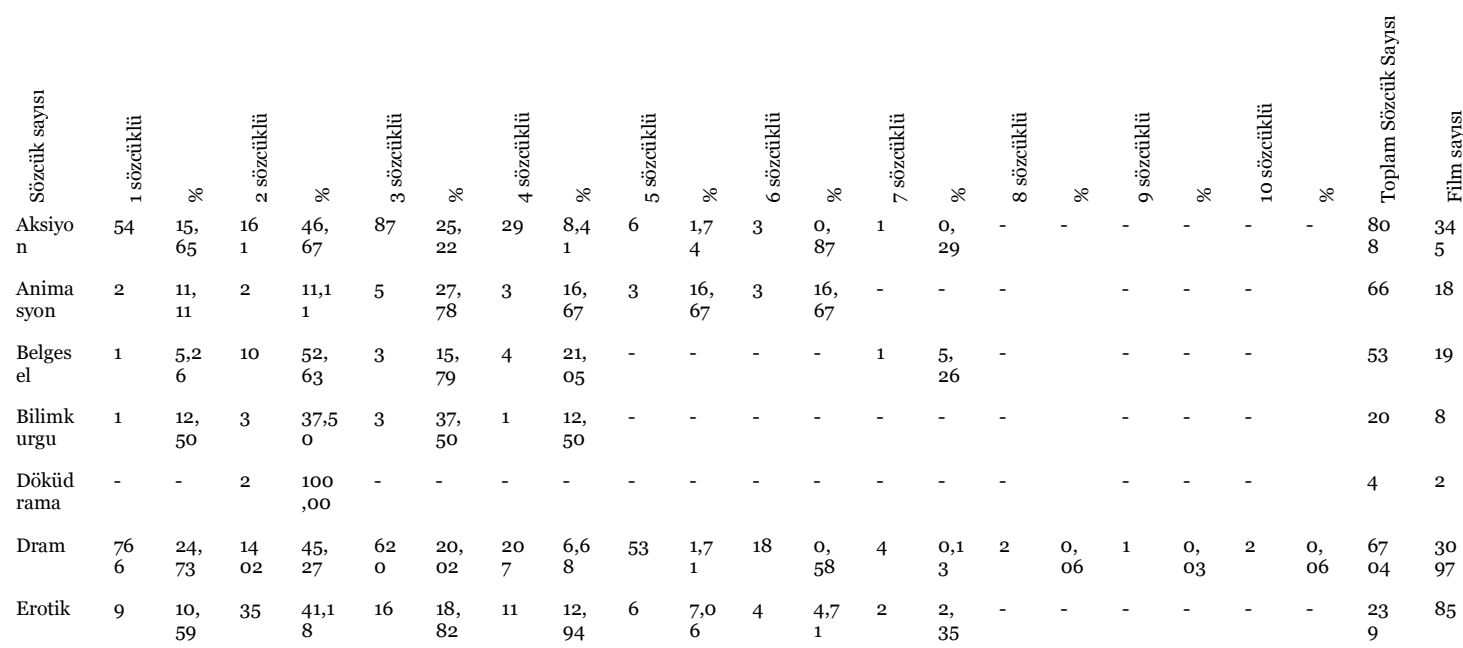

\footnotetext{
Adres Address

RumeliDE Dil ve Edebiyat Araştırmalar Dergisi $\quad$ RumeliDE Journal of Language and Literature Studies Osmanağa Mahallesi, Mürver Çiçeği Sokak, No:14/8 $\quad$ Osmanağa Mahallesi, Mürver Çiçeği Sokak, No:14/8 Kadıköy - ISTANBUL / TÜRKIYE 34714 Kadıköy - ISTANBUL / TURKEY 34714 e-posta: editor@rumelide.com e-mail: editor@rumelide.com, tel: +90 505 7958124, +90 2167730616 phone: +90 505 7958124, +90 2167730616
} 


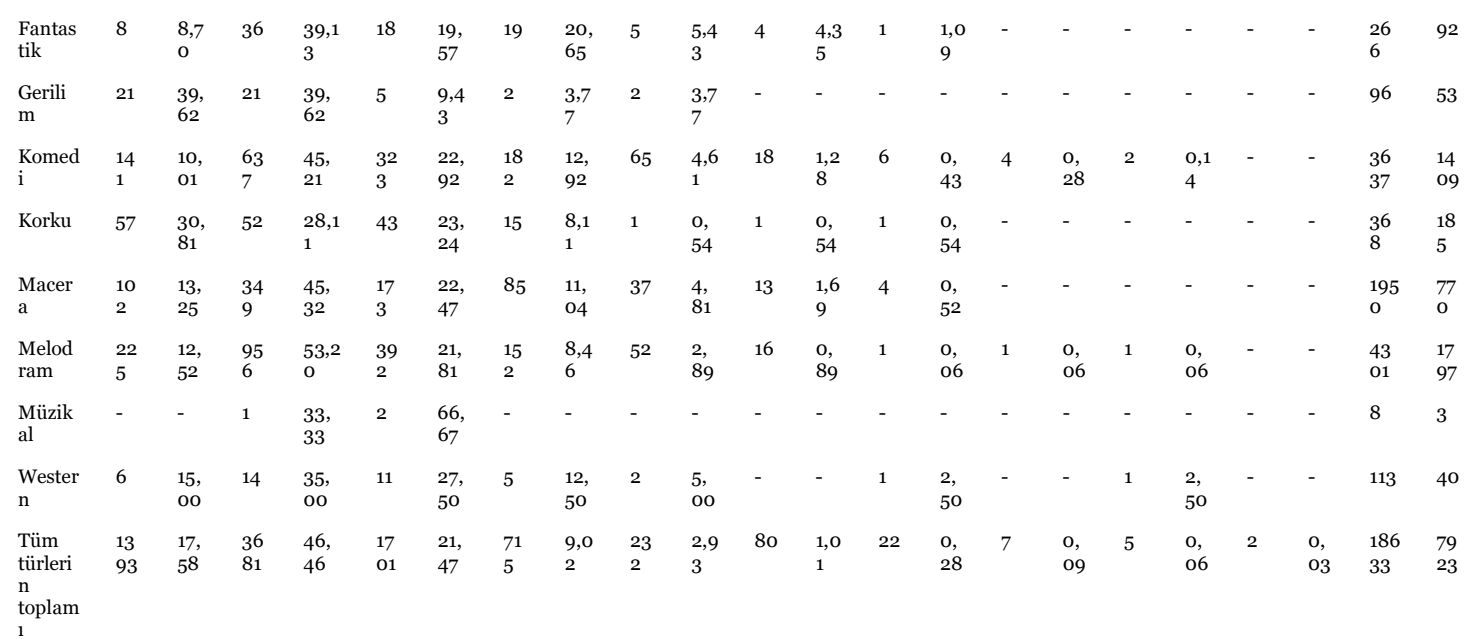

Tablo 4.te film adlarının türlere göre kaçar sözcükten oluştukları, türlere göre toplam sözcük sayıları ve bunların yüzdelik oranları verilmiştir. TFAD'da en uzun film adı 10 sözcükten oluşmakta ve iki örneği bulunmaktadır. İkisi de dram türünde olan bu filmlerin adları şöyledir: İstanbul'da Bir Facia-i Aşk (Şişli Güzeli Mediha Hanımın Facia-i Katli) (1922), Orhan Pamuk’a Söylemeyin Kars’ta Çektiğim Filmde Kar Romanı da Var (2016).

İki sözcükten oluşan film adları hemen hemen tüm film türlerinde sayı bakımından en yüksektir. Bu durumun istisnası animasyon, korku ve müzikal türündeki filmlerdir. Burada dikkat çeken husus korku türündeki film sayısının çok düşük olmamasına rağmen diğer film türlerinden farklı olarak daha çok, tek sözcükten oluşmasıdır.

Tüm türlerin sayılarına bakıldığında ilk sırada iki sözcükten oluşan, ikinci sırada üç sözcükten oluşan, üçüncü olarak da tek sözcükten oluşan film adları olduğu görülmektedir. Yüksek adetli film türleri arasında oransal olarak iki sözcükten oluşan film adları en baskın olarak melodram türündedir.

Tek sözcükten oluşan film adlarında en yüksek oran gerilim ve korku türündedir. Tür özellikleri olarak birbirine yakın olan türlerde oranların yüksek olması dikkat çekicidir. Sıralama aksiyon, komedi, dram ve macera biçiminde devam etmektedir.

Üç sözcükten oluşan film adlarında en yüksek oran müzikal türünde, en düşük oran ise gerilim türündedir.

Dört sözcükten oluşan film adlarında en yüksek oran belgesel türünde, en düşük oran ise gerilim türündedir.

Beş sözcükten oluşan film adlarında en yüksek oranlar animasyon, bilimkurgu, erotik türlerinde iken en düşük oran dram ve korku türündedir.

Aksiyon, erotik, komedi, macera, melodram ve western türündeki film adları ikincil olarak üç sözcükten oluşurken dram türü bu durumun dışında kalarak ikincil olarak tek sözcükten oluşmaktadır. Dram, komedi ve melodram gibi film türlerinde az olmakla birlikte 7, 8, 9 sözcük gibi uzun film adları örnekleri bulunmaktadır.

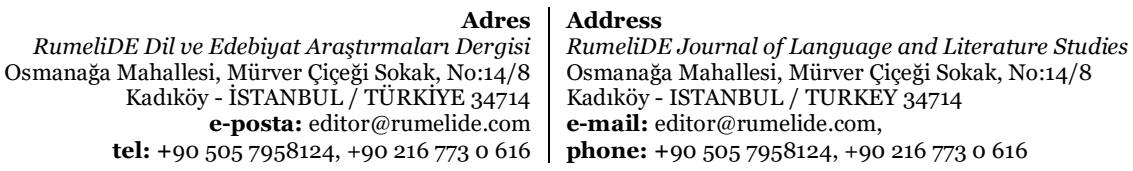


Tüm türlerin toplam oranına göre sözcük sayılarına bakıldığında sıralamanın iki sözcükten, üç sözcükten, bir sözcükten ve dört sözcükten oluşan film adları biçiminde olduğu görülmektedir.

\subsection{Ad uzunluğu}

Tablo 5: Türlere göre film adı uzunluğu

$\begin{array}{lllll}\text { Türler } & \text { Sözcük sayısı } & \text { Film sayısı } & \text { Sözcük uzunluğu } & \text { Ortalama üstü/altı } \\ \text { Aksiyon } & 808 & 345 & 2,34 & \downarrow \\ \text { Animasyon } & 66 & 18 & 3,67 & \uparrow \\ \text { Belgesel } & 53 & 19 & 2,79 & \uparrow \\ \text { Bilimkurgu } & 20 & 8 & 2,50 & \uparrow \\ \text { Döküdrama } & 4 & 2 & 2,00 & \downarrow \\ \text { Dram } & 6704 & 3097 & 2,16 & \downarrow \\ \text { Erotik } & 239 & 85 & 2,81 & \uparrow \\ \text { Fantastik } & 266 & 92 & 2,89 & \uparrow \\ \text { Gerilim } & 96 & 53 & 1,81 & \downarrow \\ \text { Komedi } & 3637 & 1409 & 2,58 & \uparrow \\ \text { Korku } & 368 & 185 & 1,99 & \uparrow \\ \text { Macera } & 1950 & 770 & 2,53 & \uparrow \\ \text { Melodram } & 4301 & 1797 & 2,39 & \uparrow \\ \text { Müzikal } & 8 & 3 & 2,67 & \uparrow \\ \text { Western } & 113 & 40 & 2,83 & - \\ \text { Toplam } & 18633 & 7923 & 2,35 & \end{array}$

Tablo 5.te film adı uzunlukları gösterilmiştir. Filmlerin tüm türlere göre sözcük ortalaması genel olarak ele alındığında bir film adının ortalama 2,35 sözcükten oluştuğu görülmektedir. Ortalama, türlere göre incelendiğinde en yüksek sözcük ortalamasının animasyon, fantastik, western ve erotik türlerinde, en düşük sözcük ortalamasının gerilim, korku, döküdrama türlerinde olduğu görülmektedir. Film sayısının en yüksek olduğu türlerde sözcük ortalaması siralaması şöyledir: komedi 2,58, melodram 2,39, dram 2,16. Sözcük uzunluğu bakımından en düşük değerler ise gerilim, döküdrama, korku ve dram türlerindedir. Tür özellikleri birbirinde yakın olan gerilim ve korku film türlerinde sözcük uzunluğu değerinin düşük olması dikkat çekicidir.

\section{5•3. Sözcük sıklıkları}

\subsubsection{Genel sözcük sıklığı}

Bu bölümde film adlarında yer alan sözcük sıklıkları TFAD'daki tüm filmler, türlerine göre ayrılmaksızın ele alınmıştır.

\section{5•3.1.1. Ad soylu sözcüklerin sıklı̆̆ı}

TFAD'daki ad soylu sözcüklerin toplam sayısı 1690o'dür.

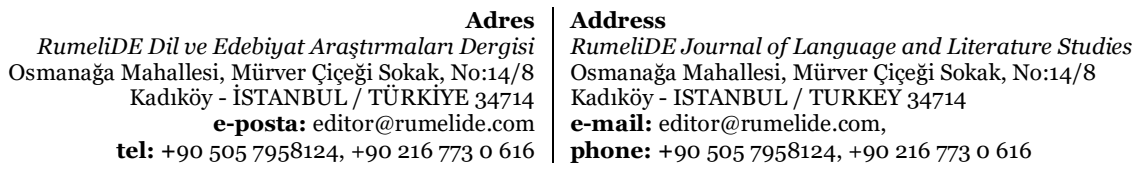


Tablo 6: Ad soylu sözcüklerin siklı̆̆ı

$\begin{array}{llllllll}\text { Sira } & \text { Ad soylu sözcük } & \text { Sıklı Sayısı } & \% & \text { Sira } & \text { Ad soylu sözcük } & \text { Siklık Sayısı } & \% \\ \mathbf{1} & \text { bir } & 323 & 1,911 & \mathbf{1 6} & \text { hayat } & 79 & 0,467 \\ \mathbf{2} & \text { aşk } & 266 & 1,574 & \mathbf{1 7} & \text { acı } & 72 & 0,426 \\ \mathbf{3} & \text { ben } & 219 & 1,295 & \mathbf{1 8} & \text { dünya } & 69 & 0,408 \\ \mathbf{4} & \text { kız } & 200 & 1,183 & \mathbf{1 9} & \text { iki } & 69 & 0,408 \\ \mathbf{5} & \text { kadın } & 199 & 1,177 & \mathbf{2 0} & \text { gün } & 68 & 0,402 \\ \mathbf{6} & \text { ve } & 146 & 0,863 & \mathbf{2 1} & \text { İstanbul } & 68 & 0,402 \\ 7 & \text { sen } & 134 & 0,792 & \mathbf{2 2} & \text { kan } & 68 & 0,402 \\ \mathbf{8} & \text { ölüm } & 115 & 0,680 & \mathbf{2 3} & \text { yol } & 68 & 0,402 \\ \mathbf{9} & \text { adam } & 114 & 0,674 & \mathbf{2 4} & \text { güzel } & 67 & 0,396 \\ \mathbf{1 0} & \text { kara } & 105 & 0,621 & \mathbf{2 5} & \text { üç } & 65 & 0,384 \\ \mathbf{1 1} & \text { ile } & 102 & 0,603 & \mathbf{2 6} & \text { gelin } & 63 & 0,372 \\ \mathbf{1 2} & \text { gece } & 93 & 0,550 & \mathbf{2 7} & \text { çocuk } & 60 & 0,355 \\ \mathbf{1 3} & \text { son } & 88 & 0,520 & \mathbf{2 8} & \text { biz } & 59 & 0,349 \\ \mathbf{1 4} & \text { kader } & 87 & 0,514 & \mathbf{2 9} & \text { kral } & 59 & 0,349 \\ \mathbf{1 5} & \text { baba } & 80 & 0,473 & \mathbf{3 0} & \text { var } & 58 & 0,343\end{array}$

Tablo 6.da veri tabanındaki tüm film adlarındaki ad soylu sözcükler arasında en sık kullanılan 30 sözcük (gövdelenmiş) ve ad soyluların toplam sayısına göre yüzdelik oranı gösterilmiştir.

Tabloda görüleceği üzere en sık kullanılan sözcükler arasında "bir”, "ben”, “sen”, "ve”, “ile”, "biz” gibi işlev sözcükleri bulunmaktadır. Türkçe için yapılmış genel derlemlerde de en sık kullanılan sözcükler arasında işlev sözcüklerinin sıklık listelerinin üst sıralarında olduğu bilinmektedir (Aksan ve diğerleri, 2016). Sıklık sayısı açısından "ben" adılı "sen" adılının yaklaşık iki katıdır. Film adlarında ben üzerinden anlatım daha yüksek miktardadır.

Bu listede işlev sözcükleri dışındaki sözcükler haricinde en sık kullanılan sözcükler olarak "aşk”, "kız", "kadın”, “ölüm”, ”adam” gelmektedir. Bu sözcüklerin sıklık listesinde yukarılarda olmasının temel nedenlerinden biri olarak TFAD içinde dram ve melodram türündeki film sayısının öteki türlere göre fazla olmasını öne sürmek yanlış olmayacaktır. Zira bu sözcükler doğal olarak bu film türlerini çağrıştırmaktadır. Öte yandan sıklık listesindeki sözcüklerin dikkat çekici diğer özelliği "kız", "kadın" gibi dişillik bildiren sözcüklerin "adam", "baba” gibi erillik bildiren sözcüklere göre daha üst siralarda olmasidır.

Sıklık bakımından üst sıralardaki ilginç sözcüklerden biri de "kral"dır. Türk tarihindeki yönetim modelleriyle bir ilgisi bulunmayan yabancı kökenli bu sözcük Memiş ile İbiş Anaforcular Kralı (1952), Gol Kralı Cafer (1962), Kilink Caniler Kralı (1967), Horoz Nuri Çapkınlar Kralı (1965), Çöpçüler Kralı (1977), Dalavereciler Kralı (1955), Turist Ömer Dümenciler Kralı (1965) vb. film adlarında temel anlamından ziyade "herhangi bir alanda çok başarılı, en başarılı" mecaz anlamında kullanılmıştır.

Ayrıca bu listeye özel ad olarak İstanbul sözcüğü girmiştir. “İstanbul” sözcüğünün sıklık listesinde üst sıralarda bulunmasını filmlerin yapım merkezi olması, kültür hayatındaki öneminin öteki illere göre fazla oluşu, nüfusunun hemen her dönemde diğer illere göre yüksek olması gibi durumlarla açılamak mümkündür.

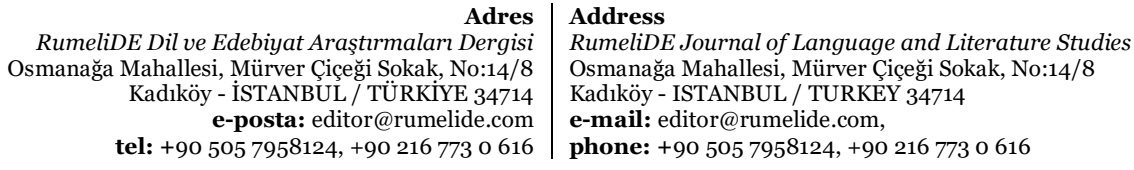


Tablo 7: TUD’da en sık kullanılan 30 ad soylu sözcük (Aksan vd., 2016)

\begin{tabular}{|c|c|c|c|}
\hline Sira & Ad Soylu Sözcük & Sura & Ad Soylu Sözcük \\
\hline 1 & bir & 16 & sonra \\
\hline 2 & ve & 17 & yer \\
\hline 3 & $\mathrm{bu}$ & 18 & ama \\
\hline 4 & da & 19 & zaman \\
\hline 5 & o & 20 & her \\
\hline 6 & ben & 21 & şey \\
\hline 7 & için & 22 & kadar \\
\hline 8 & çok & 23 & en \\
\hline 9 & ne & 24 & yll \\
\hline 10 & daha & 25 & değil \\
\hline 11 & gibi & 26 & biz \\
\hline 12 & kendi & 27 & gün \\
\hline 13 & $\mathrm{mi}$ & 28 & insan \\
\hline 14 & var & 29 & ya \\
\hline 15 & ile & 30 & el \\
\hline
\end{tabular}

Tablo 7.de genel bir dil derlemi olarak hazırlanmış Türkçe Ulusal Derlemi’nde (TUD) en sık kullanılan 30 ad soylu sözcük gösterilmiştir.

İki liste karşılaştırıldığında ortaya çıkan ilk fark ilgeç, bağlaç, adıl gibi işlev sözcüklerinin TUD listesinde TFAD listesine göre fazla oluşudur. TUD'da 15 işlev sözcüğü varken TFAD'da 5 işlev sözcüğü vardır. Bu iki liste arasında böyle bir farkın olmasının nedeni TUD'daki verilerin ağırlıklı biçimde tümce olmasından kaynaklıdır. TUD tümcelerden oluştuğu için sıklık listesinin ilk sıralarını işlev sözcükleri almaktadır.

TFAD'da ve TUD'daki en sık kullanılan 30 ad soylu sözcük karşılaştırıldığında “ben”, "bir”, "biz”, "gün”, "ile", "var", "ve” olmak üzere 7 sözcüğün ortak, her bir listede 23 sözcüğün farklı olduğu görülmektedir.

TFAD’daki “acı", “adam”, “aşk”, "baba”, “çocuk”, “dünya”, "gece”, "gelin”, “güzel”, "hayat”, “iki”, “İstanbul”, “kader”, "kadın”, "kan”, "kara”, "kız”, "kral”, “ölüm”, “sen”, “son”, “üȩ”, “yol” sözcükleri TUD’un en sık kullanılan ilk 30 ad soylu sözcük listesinde yoktur.

TUD’daki “ama”, “bu”, “çok”, ”da”, “daha”, “değil”, “el”, “en”, “gibi”, “her”, “için”, “insan”, "kadar”, "kendi”, “mi”, "ne”, “o”, “sonra”, "şey”, “ya”, ”yer”, ”yll”, "zaman” eylemleri TFAD’daki en sik kullanılan 30 ad soylu sözcük listesinde yoktur.

Bu bölümde en sık kullanılan adlardan üç tanesinin çekimli biçimleri (sözbiçimleri) irdelenmeye çalışılmıştır. 
Tablo 8: "aşk” sözcügünün türlere göre sözbiçimleri

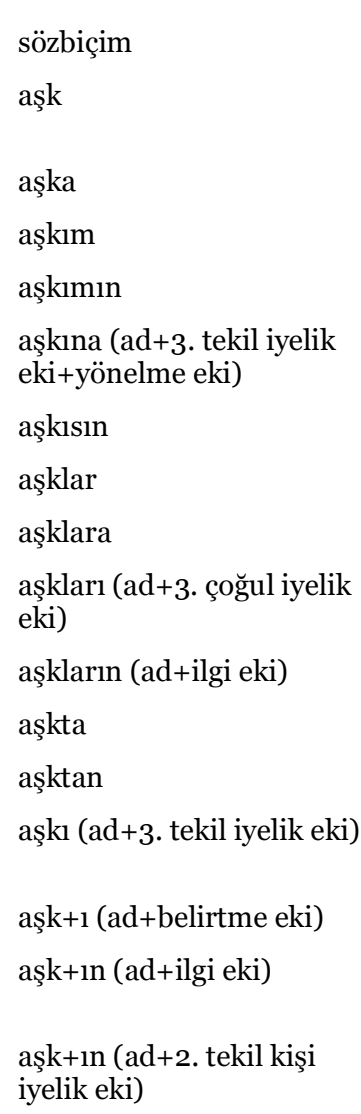

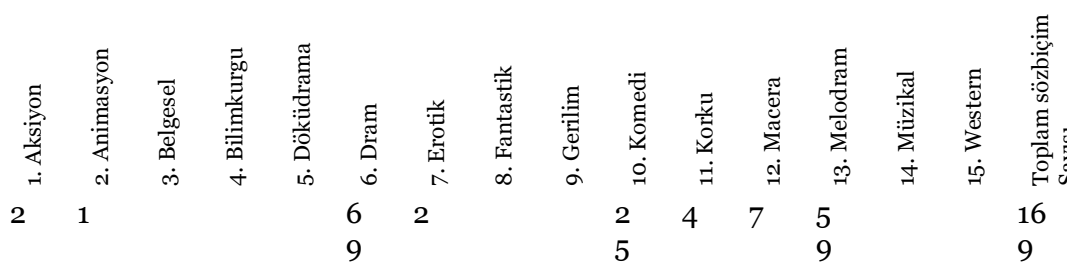$$
3
$$$$
3 \quad 1
$$$$
1
$$$$
1
$$$$
1
$$$$
36
$$$$
13
$$$$
5
$$$$
9
$$$$
1
$$$$
1
$$

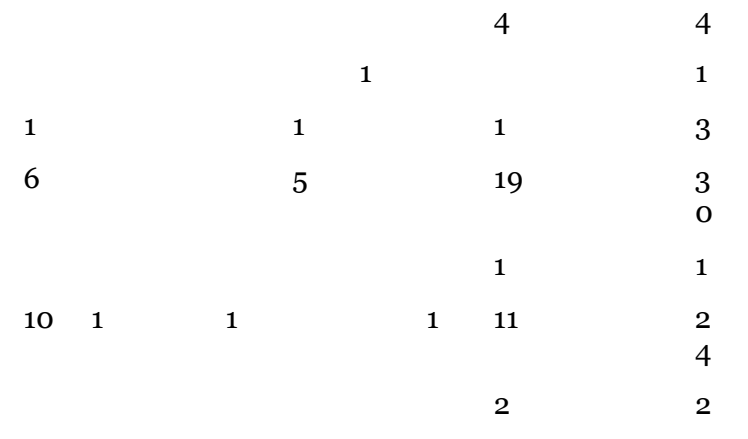

Tablo 8.de "aşk” sözcüğünün sözbiçimleri gösterilmiştir. "aşk” sözcüğünün 16 farklı sözbiçimi bulunmaktadır. Film adları, Arkadaşımın Aşkısın Kan Kardeşim (1968), Bütün Aşklar Tatlı Başlar (1970) gibi istisnai örnekleri olmakla birlikte, genel olarak tümce yapısına sahip olmadığı için yönelme $+\{(\mathrm{y}) \mathrm{A}\}$, ayrılma $+\{\mathrm{DAn}\}$, belirtme $+\{(1) \mathrm{I}\}$ gibi durum eklerini almış sözcüklerin sayısı daha azdır. İlgi eki, iyelik eki gibi tamlama yapılmasını sağlayan eklerin sayısı durum eklerine göre daha yüksektir. Eklerle ilgili dikkat çeken önemli bir özellik III. tekil kişi iyelik eklerinin öteki kişileri gösteren iyelik eklerine göre fazla oluşudur. Dolayısıyla film adlarında III. tekil kişi üzerinden anlatımının ağırlığı ön plana çıkmaktadır. 
Tablo 9: "kız" sözcüğünün türlere göre sözbiçimleri

\begin{tabular}{|c|c|c|c|c|c|c|c|c|c|c|c|c|c|c|c|c|}
\hline & 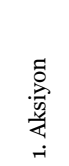 & 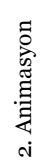 & 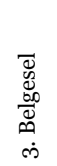 & 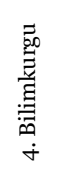 & 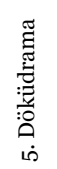 & 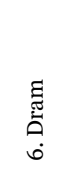 & 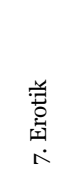 & 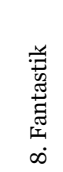 & 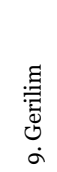 & 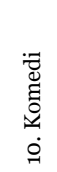 & 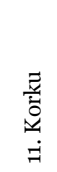 & 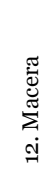 & 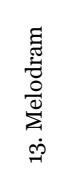 & 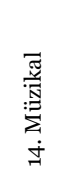 & 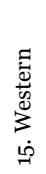 & 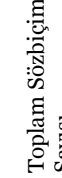 \\
\hline kiz & 1 & & & & & 16 & 2 & 5 & & $\begin{array}{l}2 \\
3\end{array}$ & & 1 & $\begin{array}{l}3 \\
0\end{array}$ & & & $\begin{array}{l}7 \\
8\end{array}$ \\
\hline kıza & & & & & & & & & & & & & & 1 & & 1 \\
\hline $\begin{array}{l}\text { kızım (ad+1. tekil kişi iyelik } \\
\text { eki) }\end{array}$ & & & & & & 5 & & & & & & 1 & 4 & & & 10 \\
\hline kızıma & & & & & & & & & & & & & 1 & & & 1 \\
\hline kızımı & & & & & & 1 & & & & & & & & & & 1 \\
\hline $\begin{array}{l}\text { kızımın (ad+1. tekil kişi } \\
\text { iyelik eki+ilgi eki) }\end{array}$ & & & & & & 2 & & & & & & & & & & 2 \\
\hline kızımla & & & & & & & & & & & & & 1 & & & 1 \\
\hline kızın (ad+ilgi eki) & & & & & & 4 & & & & & & & 7 & & & 11 \\
\hline $\begin{array}{l}\text { kızını (ad+3.tekil kişi iyelik } \\
\text { eki+belirtme }\end{array}$ & & & & & & 1 & & & & 2 & & & & & & 3 \\
\hline kızlar & & & & & & 5 & 3 & & & 13 & & 2 & 5 & & & $\begin{array}{l}2 \\
8\end{array}$ \\
\hline kızlara & & & & & & & & & & & & & 1 & & & 1 \\
\hline $\begin{array}{l}\text { kızları (ad+3. çoğul kişi } \\
\text { iyelik eki) }\end{array}$ & 2 & & & & & 1 & 3 & & 1 & 2 & & 1 & & & & 10 \\
\hline $\begin{array}{l}\text { kızların (ad+çokluk eki+ilgi } \\
\text { eki) }\end{array}$ & & & & & & & & & & 1 & & & 1 & & & 2 \\
\hline $\begin{array}{l}\text { kızı (ad+3.tekil kişi iyelik } \\
\text { eki) }\end{array}$ & 1 & & & & & 11 & 1 & & & 5 & 1 & 2 & $\begin{array}{l}3 \\
0\end{array}$ & & & 51 \\
\hline
\end{tabular}

Tablo 9.da "kız" sözcüğünün çekim eki almış biçimleri gösterilmiştir. "kız" sözcüğünün 14 farklı sözbiçimi bulunmaktadır. Film adları genellikle tümce yapısında olmadığı için yönelme, çıkma, belirtme gibi durum eklerini almış sözcüklerin sayısı yalın biçimdeki sözcüklere göre daha azdır. "kız" sözcüğünde 26 adet I. tekil kişi iyelik biçimli, 54 adet III. tekil kişi iyelik ekli sözbiçim bulunmaktadır. 
Tablo 1o: "kadın” sözcüğünün türlere göre sözbiçimleri

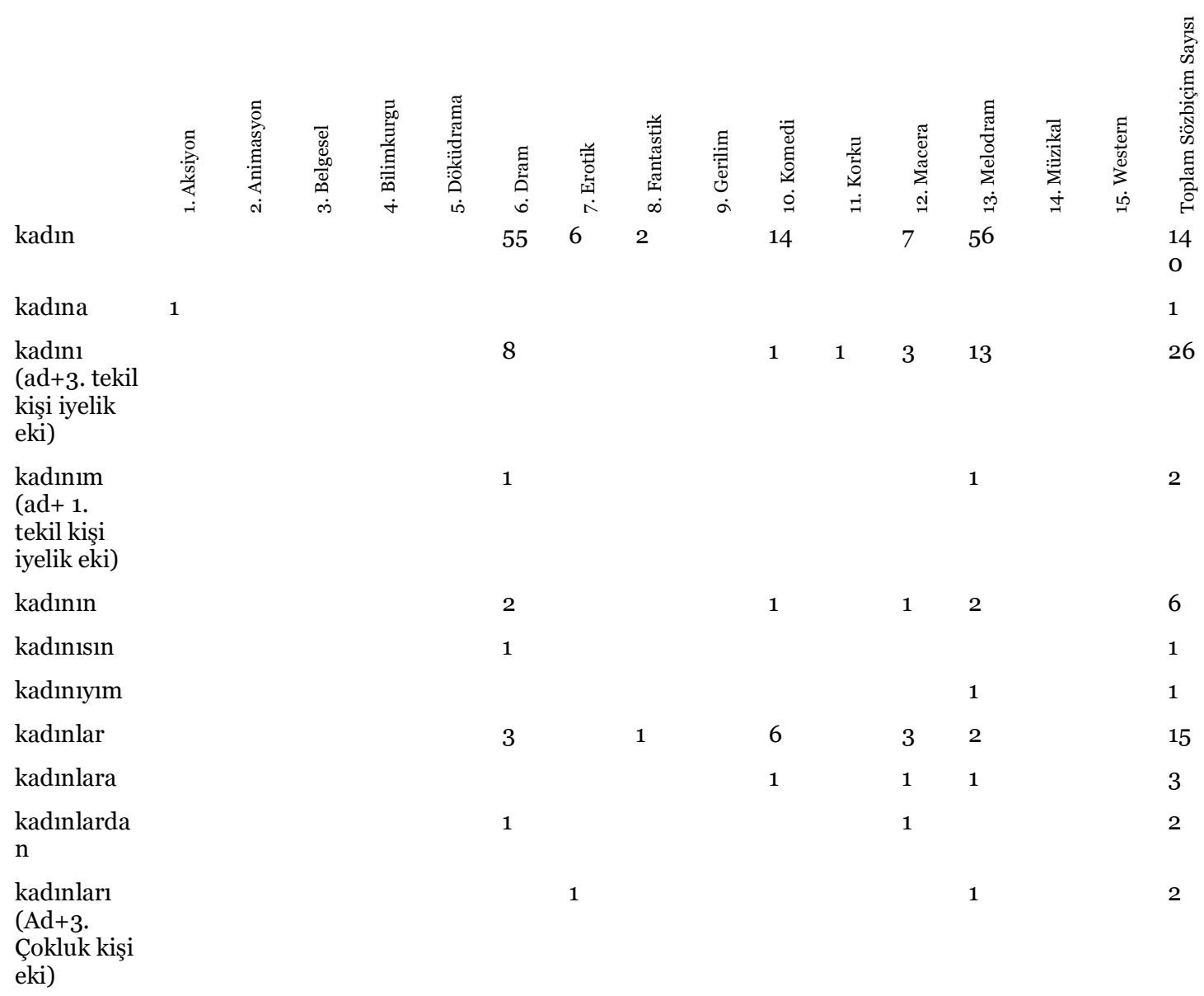

Tablo 10.da "kadın” sözcüğünün çekim eki almış biçimleri gösterilmiştir. "kadın” sözcüğünün 11 farklı sözbiçimi vardır. "kadın" sözcüğünün en fazla örneği olan sözbiçimi yalın ve III. tekil kişi iyelik ekli $+\{(\mathrm{s}) \mathrm{I}\}$ biçimidir. Bu biçimin fazla oluşunun nedeni Felaket Kadını (1960), Macera Kadını (1964), Toplumun Kadını (1988), Bu Devrin Kadını (1988), Ev Kadını (2017) örneklerinde görüleceği üzere "kadın" sözcüğünün ad tamlamaları içinde fazla olmasıdır.

\section{5•3.1.2. Eylemlerin sıklığı}

TFAD'da toplam 1733 eylem kullanılmıştır.

Tablo 11: Eylem siklığı

\begin{tabular}{|c|c|c|c|c|c|c|c|}
\hline Sira & Eylem & Sıklık Sayısı & $\%$ & Sira & Eylem & Sıklık Sayısı & $\%$ \\
\hline $\mathbf{1}$ & sev- & 126 & 7,2706 & 16 & bekle- & 19 & 1,0964 \\
\hline 2 & ol- & 112 & 6,4628 & 17 & gör- & 19 & 1,0964 \\
\hline 3 & gel- & 84 & 4,8471 & 18 & affet- & 18 & 1,0387 \\
\hline 4 & öl- & 63 & 3,6353 & 19 & et- & 18 & 1,0387 \\
\hline 5 & ağla- & 49 & 2,8275 & 20 & gül- & 18 & 1,0387 \\
\hline 6 & de- & 41 & 2,3658 & 21 & bul- & 17 & 0,981 \\
\hline & & $\begin{array}{r}\text { DE Dil ve Edebiya } \\
\text { Mahallesi, Mürve } \\
\text { Kadıköy - İSTAI } \\
\text { e-posta } \\
\text { tel: +90 } 505795\end{array}$ & $\begin{array}{l}\text { Ad } \\
\text { maları Der } \\
\text { okak, No:1 } \\
\text { JRKiYE } 34 \\
\text { rumelide.c } \\
216773 \text { o }\end{array}$ & \multicolumn{4}{|c|}{$\begin{array}{l}\text { Address } \\
\text { RumeliDE Journal of Language and Literature Studies } \\
\text { Osmanağa Mahallesi, Mürver Çiçeği Sokak, No:14/8 } \\
\text { Kadıöy- ISTANBUL / TURKEY } 34714 \\
\text { e-mail: editor@rumelide.com, } \\
\text { phone: +90 505 7958124, +90 } 216773 \text { o } 616\end{array}$} \\
\hline
\end{tabular}




$\begin{array}{llllllll}7 & \text { vur- } & 39 & 2,2504 & \mathbf{2 2} & \text { ver- } & 17 & 0,981 \\ \mathbf{8} & \text { git- } & 37 & 2,135 & \mathbf{2 3} & \text { düş- } & 16 & 0,9233 \\ \mathbf{9} & \text { yaşa- } & 36 & 2,0773 & \mathbf{2 4} & \text { unut- } & 16 & 0,9233 \\ \mathbf{1 0} & \text { öldür- } & 34 & 1,9619 & \mathbf{2 5} & \text { al- } & 14 & 0,8078 \\ \mathbf{1 1} & \text { kal- } & 28 & 1,6157 & \mathbf{2 6} & \text { bak- } & 14 & 0,8078 \\ \mathbf{1 2} & \text { bit- } & 23 & 1,3272 & \mathbf{2 7} & \text { kaç- } & 13 & 0,7501 \\ \mathbf{1 3} & \text { iste- } & 22 & 1,2695 & \mathbf{2 8} & \text { çı- } & 12 & 0,6924 \\ \mathbf{1 4} & \text { doğ- } & 21 & 1,2118 & \mathbf{2 9} & \text { geç- } & 12 & 0,6924 \\ \mathbf{1 5} & \text { dön- } & 20 & 1,1541 & \mathbf{3 0} & \text { konuş- } & 12 & 0,6924\end{array}$

Tablo 11.de TFAD içindeki tüm film adlarında geçen eylemlerin sıklık sırası gösterilmiştir. "ol-“ eylemi yardımcı eylem olduğu için Türkçede yüksek sıklıkta kullanılmaktadır. "sev-”, “öl-”, “ağla-”, “dön-”, "bekle-", "affet-", gibi eylemlerin sıklık listesinde en üst sıralarda bulunmasının temel nedenini TFAD'da dram ve melodram türündeki film sayısının öteki türlere göre fazla oluşu biçiminde değerlendirmek mümkündür. Bu noktada dikkat çekici bir husus "de-“, "git-”, "kal-“, "iste-“, "doğ-“ gibi film türlerine ait doğrudan bir ilişkisi bulunmayan eylemlerin listede üst sıralarda bulunmasıdır.

Tablo 12: TUD'da en sik kullanılan 30 eylem (Aksan vd., 2016: s.247)

$\begin{array}{llll}\text { Sira } & \text { Eylem } & \text { Sira } & \text { Eylem } \\ \mathbf{1} & \text { et- } & \mathbf{1 6} & \text { yaşa- } \\ \mathbf{2} & \text { çlk- } & \mathbf{1 7} & \text { kaç- } \\ \mathbf{3} & \text { gör- } & \mathbf{1 8} & \text { karşıla- } \\ \mathbf{4} & \text { anla- } & \mathbf{1 9} & \text { söyle- } \\ \mathbf{5} & \text { bul- } & \mathbf{2 0} & \text { yaz- } \\ \mathbf{6} & \text { geç- } & \mathbf{2 1} & \text { de- } \\ 7 & \text { yap- } & \mathbf{2 2} & \text { ayır- } \\ \mathbf{8} & \text { al- } & \mathbf{2 3} & \text { kullan- } \\ \mathbf{9} & \text { tut- } & \mathbf{2 4} & \text { duy- } \\ \mathbf{1 0} & \text { ol- } & \mathbf{2 5} & \text { oku- } \\ \mathbf{1 1} & \text { tan- } & \mathbf{2 6} & \text { çalış- } \\ \mathbf{1 2} & \text { sev- } & \mathbf{2 7} & \text { at- } \\ \mathbf{1 3} & \text { çek- } & \mathbf{2 8} & \text { sür- } \\ \mathbf{1 4} & \text { bil- } & \mathbf{2 9} & \text { gir- } \\ \mathbf{1 5} & \text { ver- } & \mathbf{3 0} & \text { ara- }\end{array}$

Tablo 12.de genel bir dil derlemi olarak hazırlanmış Türkçe Ulusal Derlemi’ndeki (TUD) en sık kullanılan 30 eylem gösterilmiştir. TFAD'da ve TUD'daki en sık kullanılan 30 eylem karşılaştıııldığında

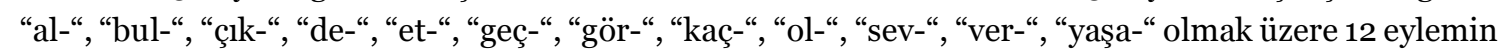
ortak, 18 eylemin farklı olduğu görülmektedir.

TFAD’daki “affet-“, “ağla-“, “bak-“, "bekle-“, “bit-“, “doğ-“, “dön-“, “düş-“, “gel-“, "git-“, "gül-“, ”iste-“, "kal-“, "konuş-“, “öl-”, “öldür-”, "unut-“, "vur-“" eylemleri TUD’un en sık kullanılan ilk 30 eylem listesinde

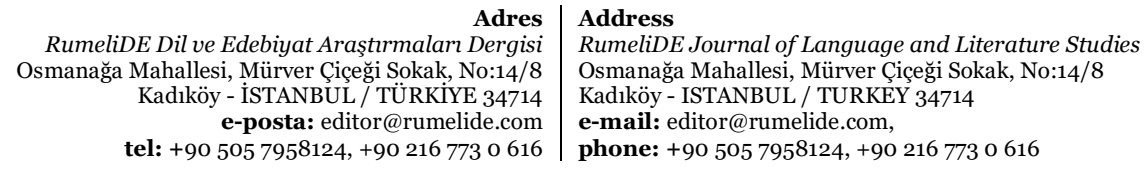


yoktur. TFAD'da en sık kullanılan eylemlerde duyguları anlatan eylemlerin ön plana çıktı̆̆ görülmektedir.

TUD’daki “anla-“, “ara-“, “at-“, "ayır-“, "bil-“, "çalış-“, “çek-“, “duy-“, "gir-“, "karşıla-“, "kullan-“, "oku-“, "söyle-“, "sür-“, "tanı-“, “tut-“, “yap-“, ”yaz-“ eylemleri TFAD’daki en sık kullanılan 30 eylem listesinde yoktur.

Tablo 13: "sev-“" eyleminin türlere göre sözbiçimleri

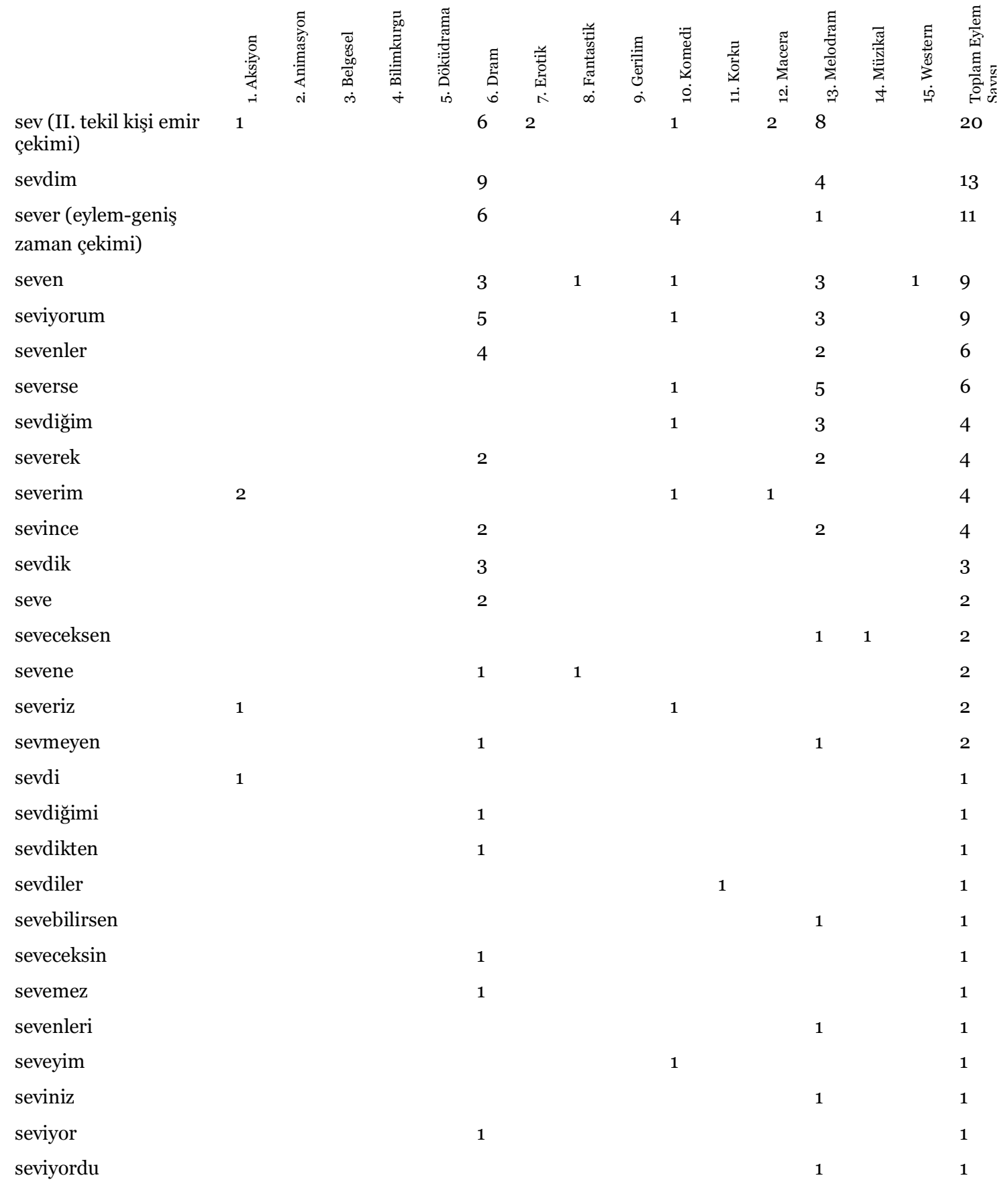




$\begin{array}{llrr}\text { seviyoruz } & 1 & 1 & 1 \\ \text { sevmedim } & & & 1 \\ \text { sevmedin } & & 1 & 1 \\ \text { sevmek } & & 1 & 1 \\ \text { sevmeli } & 1 & 1 & 1 \\ \text { sevmem } & & & 1 \\ \text { sevmemeli } & & 1 & 1 \\ \text { sevmeyeceğim } & 1 & 1 & 1 \\ \text { sevmiştik } & & 1 & 1 \\ \text { sevmiyorum } & & 1 & 1 \\ \text { sevsen } & & 1 & 1 \\ & & 1 & 1 \\ \end{array}$

Tablo 13.te "sev-" eyleminin çekimli biçimleri ve türlere göre dağılımı gösterilmiştir. Bu eylemin, film adlarında 40 farklı çekimli biçimi bulunmaktadır. En sık çekimlenmiş biçimi emir çekimidir. Daha sonra ise toplam 20 örneği bulunan $-\{(y) A n\}$ ortaç ekidir (-An, -AnlAr, -AnA, -mAyAn, -AnlArI).

Zaman açısından bu sözbiçimler değerlendirildiğinde en sık biçimlerin 24 adet geniş zaman çekimi, 22 adet bilinen geçmiş zaman çekimi olduğu görülmektedir. Duyulan geçmiş zamanın hiç örneğinin bulunmaması dikkat çekicidir.

Kişi işaretlenmesi açısından değerlendirildiğinde 36 eylemde I. tekil kişinin, 26 eylemde II. tekil kişinin, 23 eylemde III. tekil kişinin, 7 eylemde I. çoğul kişinin, 1 eylemde II. çoğul kişinin, 8 eylemde III. çoğul kişinin işaretlendiği görülmektedir. Dolayısıyla "sev-“ eyleminde I ve II. Tekil kişi işaretlemesinin baskın biçimde yüksek olduğu ortaya çıkmaktadır.

Olumlu - olumsuz işaretlenme söz konusu olduğunda ise 9 eylemin olumsuz, 117 eylemin olumlu işaretlendiği görülmektedir.

Tablo 14: "gel-“ eyleminin türlere göre çekimleri

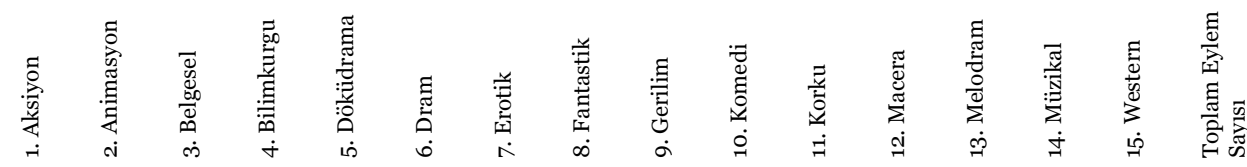

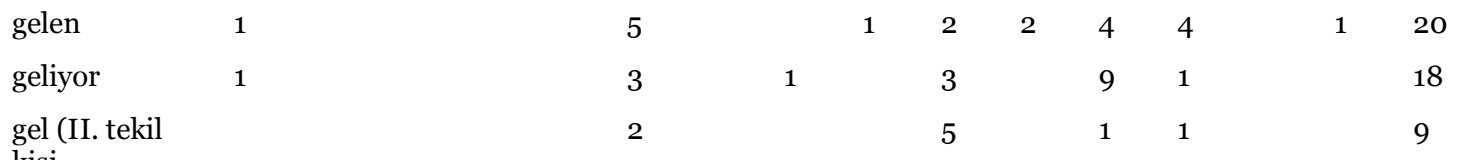

$$
\begin{aligned}
& \text { kişi } \\
& \text { emir çekimi) } \\
& \text { geliyorum } 1 \\
& \text { geldi } 2 \\
& \text { gelenler } 1 \\
& \text { geldik } 1 \\
& \text { geldin } 1 \\
& \text { gelir } \\
& \text { gelmiş } \\
& 11 \\
& \begin{array}{llllll}
1 & 2 & & 1 & 2 & 7 \\
3 & & & & & 5 \\
1 & 3 & 1 & & & 5 \\
1 & 2 & & & & 3 \\
2 & & & & & 3 \\
1 & 1 & & 1 & 2 \\
& & & &
\end{array}
\end{aligned}
$$




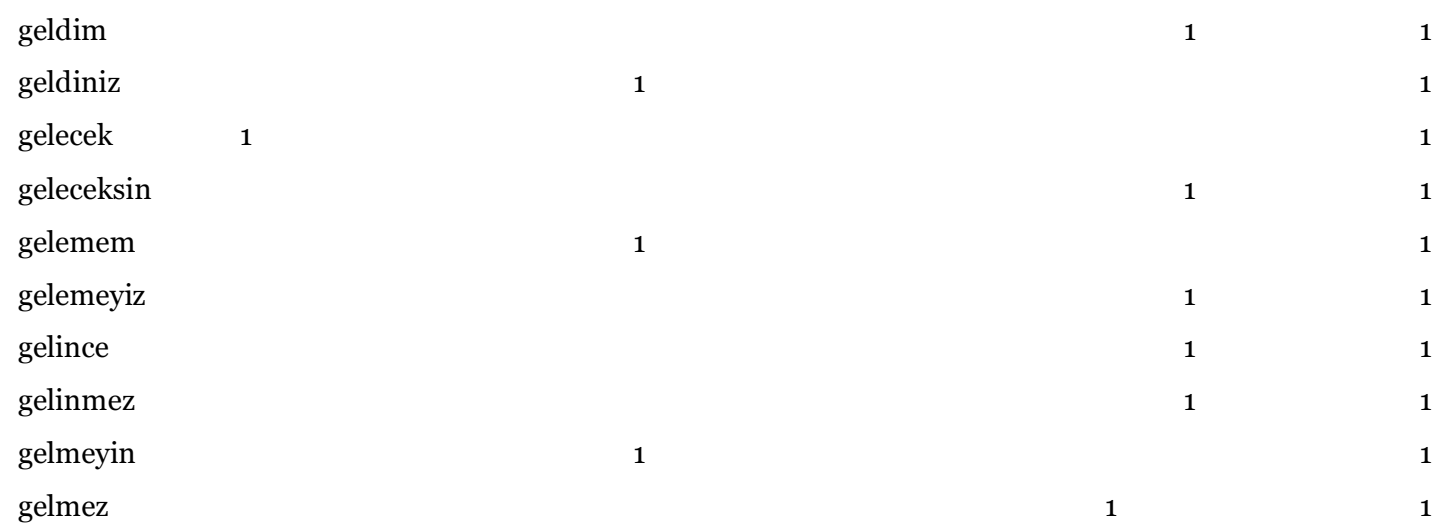

Tablo 14.te gel- eyleminin çekimli biçimleri ve türlere göre dağılımı gösterilmiştir. Bu eylemin, film adlarında 20 farklı biçimi bulunmaktadır. "gel-" eyleminin farklı çekimlenmiş biçimleri "sev-" eyleminin yarısı kadardır. En sık biçimi 25 adetle (-An, -AnlAr) ortaç ekli biçimidir.

Zaman açısından değerlendirildiğinde en sık zamanların 25 adet ile şimdi zaman çekimi, 13 adet ile bilinen geçmiş zaman çekimi olduğu görülmektedir. En az örneği olan zamanlar ise gelecek zaman ve duyulan geçmiş zaman olduğu görülmektedir.

Kişi işaretlenmesi açısından değerlendirildiğinde 9 eylemde I. tekil kişinin, 13 eylemde II. tekil kişinin, 29 eylemde III. tekil kişinin, 4 eylemde I. çoğul kişinin,2 eylemde II. çoğul kişinin, 5 eylemde III. çoğul kişinin işaretlendiği görülmektedir. "gel-“ eyleminde baskın biçimde III. tekil işaretlenmesinin yüksek olduğu dikkat çekmektedir.

Olumlu - olumsuz işaretlenme söz konusu olduğunda ise 4 eylemin olumsuz, 80 eylemin olumlu işaretlendiği görülmektedir.

Tablo 15: "gel-“ eyleminin türlere göre çekimleri

öl (II. tekil kişi emir çekimi)

öldü

öldükçe

öldükten

öldüler

öldüm

ölecek (gelecek zaman çekimi)

öleceksek

öleceksin

öleceksiniz

ölelim

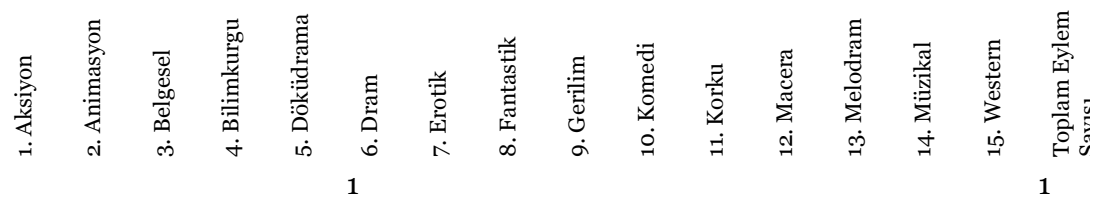

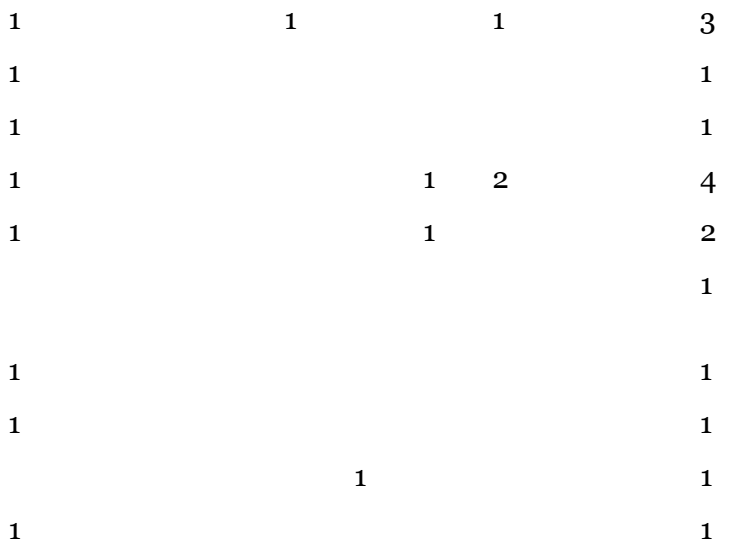

Adres | Address

RumeliDE Dil ve Edebiyat Araşturmaları Dergisi Osmanağa Mahallesi, Mürver Çiçeği Sokak, No:14/8 Kadıköy - İSTANBUL / TÜRKIYE 34714 e-posta: editor@rumelide.com

RumeliDE Journal of Language and Literature Studies Osmanağa Mahallesi, Mürver Çiçeği Sokak, No:14/8

Kadıköy - ISTANBUL / TURKEY 34714

e-mail: editor@rumelide.com,

tel: +90 505 7958124, +90 2167730616 phone: +90 505 7958124, +90 2167730616 


\begin{tabular}{|c|c|c|c|c|c|c|}
\hline ölenler & & 2 & & 1 & 2 & 5 \\
\hline ölesiye & & 2 & & & 1 & 3 \\
\hline ölmeden (eylem-ulaç) & 1 & & & & & 1 \\
\hline ölmedikçe & & & & & 1 & 1 \\
\hline ölmemeli & & 1 & & & & 1 \\
\hline ölmeli (eylem-gereklilik) & & 1 & & & & 1 \\
\hline ölmeyen & & 1 & & & 5 & 6 \\
\hline $\begin{array}{l}\text { ölmez (eylem-geniş } \\
\text { zaman olumsuz) }\end{array}$ & & 3 & & 1 & 2 & 7 \\
\hline ölmez (eylem-ortaç) & & 1 & & & & 1 \\
\hline ölmezmiş & & & & & 1 & 1 \\
\hline ölmüşüm & & & & & 1 & 1 \\
\hline ölsün & & 1 & 1 & & 1 & 3 \\
\hline ölünce & & 1 & & & & 1 \\
\hline ölünceye & & 2 & & & 1 & 3 \\
\hline ölür & 1 & 5 & & & & 6 \\
\hline ölürsün & & & & 1 & & 1 \\
\hline ölürüm & & 1 & & 2 & 2 & 5 \\
\hline
\end{tabular}

Tablo 15.te öl- eyleminin çekimli biçimleri ve türlere göre dağllımı gösterilmiştir. Bu eylemin, film adlarında 27 farklı biçimi bulunmaktadır.

En sık biçimi (-An, -AnlAr) ortaç ekli olanıdır. Bu biçimle kullanılmış 11 eylem bulunmaktadır. Ortaç ekli örneğin yüksek sayıda olmasının temel nedenini film adlarının metinsel bir yapıda olmaması ve dolayısıyla tümce hükmündeki yapı sayısının kısıtlı olması biçiminde göstermek mümkündür.

Zaman açısından değerlendirildiğinde 19 tane geniş zaman çekimi, 9 tane bilinen geçmiş zaman çekimi olduğu görülmektedir. "öl-" eyleminde baskın biçimde geniş çekimi bulunmaktadır. Öteki eylemlerde olduğu gibi bu eylemde de duyulan geçmiş zaman en az örneği bulunan çekimdir.

Kişi işaretlenmesi açısından değerlendirildiğinde 8 eylemde I. tekil kişinin, 3 eylemde II. tekil kişinin, 23 eylemde III. tekil kişinin, 2 eylemde I. çoğul kişinin,1 eylemde II. çoğul kişinin, 9 eylemde III. çoğul kişinin işaretlendiği görülmektedir. "öl-“ eyleminde baskın biçimde III. tekil işaretlenmesinin yüksek olduğu dikkat çekmektedir.

Olumlu - olumsuz işaretlenme söz konusu olduğunda ise 17 eylemin olumsuz, 46 eylemin olumlu işaretlendiği görülmektedir. "öl-“ eyleminin "sev-“ ve "gel-“ eylemlerine göre olumsuz örneği baskın biçimde daha yüksektir. 


\section{5•3.1.3. Tüm sözcüklerin durumu}

TFAD’da sözcüklerin (eylem ya da ad soylu ayırmaksızın) toplam sayısı 18633’tür.

Tablo 16: Ad ve eylem birlikte

\begin{tabular}{|c|c|c|c|c|c|c|c|}
\hline Sira & Sözcük & Siklık Sayısı & $\%$ & Sira & Sözcük & Sıklık Sayısı & $\%$ \\
\hline $\mathbf{1}$ & bir & 323 & 0,0173 & 26 & yol & 68 & 0,0036 \\
\hline 2 & aşk & 266 & 0,0142 & $\mathbf{2 7}$ & güzel & 67 & 0,0035 \\
\hline 3 & ben & 219 & 0,0117 & 28 & üç & 65 & 0,0034 \\
\hline 4 & kız & 200 & 0,0107 & 29 & gelin & 63 & 0,0033 \\
\hline 5 & kadın & 199 & 0,0106 & 30 & öl- & 63 & 0,0033 \\
\hline 6 & ve & 146 & 0,0078 & 31 & çocuk & 60 & 0,0032 \\
\hline 7 & sen & 134 & 0,0071 & 32 & biz & 59 & 0,0031 \\
\hline 8 & sev- & 126 & 0,0067 & 33 & kral & 59 & 0,0031 \\
\hline 9 & ölüm & 115 & 0,0061 & 34 & var & 58 & 0,0031 \\
\hline 10 & adam & 114 & 0,0061 & 35 & $\mathrm{bu}$ & 56 & 0,0030 \\
\hline 11 & ol- & 112 & 0,0060 & 36 & günah & 56 & 0,0030 \\
\hline 12 & kara & 105 & 0,0056 & 37 & Ali & 52 & 0,0027 \\
\hline 13 & ile & 102 & 0,0054 & 38 & intikam & $5^{2}$ & 0,0027 \\
\hline 14 & gece & 93 & 0,0049 & 39 & kardeş & 51 & 0,0027 \\
\hline 15 & son & 88 & 0,0047 & 40 & sokak & 51 & 0,0027 \\
\hline 16 & kader & 87 & 0,0046 & 41 & ne & 50 & 0,0026 \\
\hline 17 & gel- & 84 & 0,0045 & 42 & can & 49 & 0,0026 \\
\hline 18 & baba & 80 & 0,0042 & 43 & oğul & 49 & 0,0026 \\
\hline 19 & hayat & 79 & 0,0042 & 44 & sevgili & 49 & 0,0026 \\
\hline 20 & acl & 72 & 0,0038 & 45 & ağla- & 49 & 0,0026 \\
\hline 21 & dünya & 69 & o,0037 & 46 & gönül & 48 & 0,0025 \\
\hline 22 & iki & 69 & 0,0037 & 47 & gül & 48 & 0,0025 \\
\hline 23 & gün & 68 & 0,0036 & 48 & kanlı & 48 & 0,0025 \\
\hline 24 & İstanbul & 68 & 0,0036 & 49 & melek & 47 & 0,0025 \\
\hline 25 & kan & 68 & 0,0036 & 50 & ana & 46 & 0,0024 \\
\hline
\end{tabular}

Tablo 16.da TFAD'daki tüm sözcüklerin (ad soylu ve eylem ayrılmaksızın, ad soylu sözcükler ve eylemlerin toplanarak hesaplandığı) sıklık listesi gösterilmiştir. Ad soylu sözcüklerin sayısı eylemlere göre yüksektir. Tablo 15.te sadece 5 eylem varken 45 ad soylu sözcük bulunmaktadır. Aynı zamanda Türkçe için hazırlanmış sözcük sıklığı listelerinde (Aksan vd., 2016) ad soylu sözcüklerin sıklı̆̆ı da eylem soylulara göre yüksektir. Bu sıklık listesinde ad soylu sözcükler ve eylemlerin sıklığı ortak hesaplanarak sunulmuştur. Buna göre listeye eylemlerden en üst sirada giren sözcükler "sev-“, "ol-“, "gel-“ eylemleridir. Listeye özel ad olarak giren ilk ad bir il adı olan "İstanbul"dur. Özel ad olarak giren ikinci ad ise bir kişi adı olan "Ali”dir. Ali adının geçtiği Ali Kundilli filmi, 2014; Ali Kundilli 2, 2016 olmak üzere sadece iki devam filmi olmasına rağmen bu özel adın yüksek sıklıkta olması dikkat çekicidir. Zira "Kara Murat", "Cilalı İbo" gibi devam filmleri olan özel adların sıklık bakımından yüksek olması normaldir. Öte yandan Türkiye'de en sık kullanılan erkek adı olan "Mehmet" en sık 50 sözcüğün yer aldığı bu listeye girememiştir.

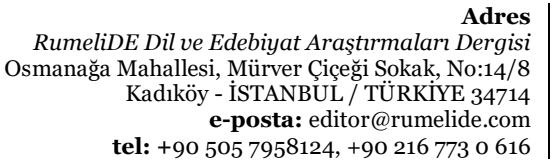

Adres (4)

RumeliDE Journal of Language and Literature Studies Osmanağa Mahallesi, Mürver Çiçeği Sokak, No:14/8 Kadıköy - ISTANBUL / TURKEY 34714

e-mail: editor@rumelide.com, phone: +90 $5057958124,+902167730616$ 


\section{5•3.2. Türlere göre sözcük sılklı̆̆ı}

\subsubsection{Film türlerine göre ad soylu sözcüklerin sıklıkları}

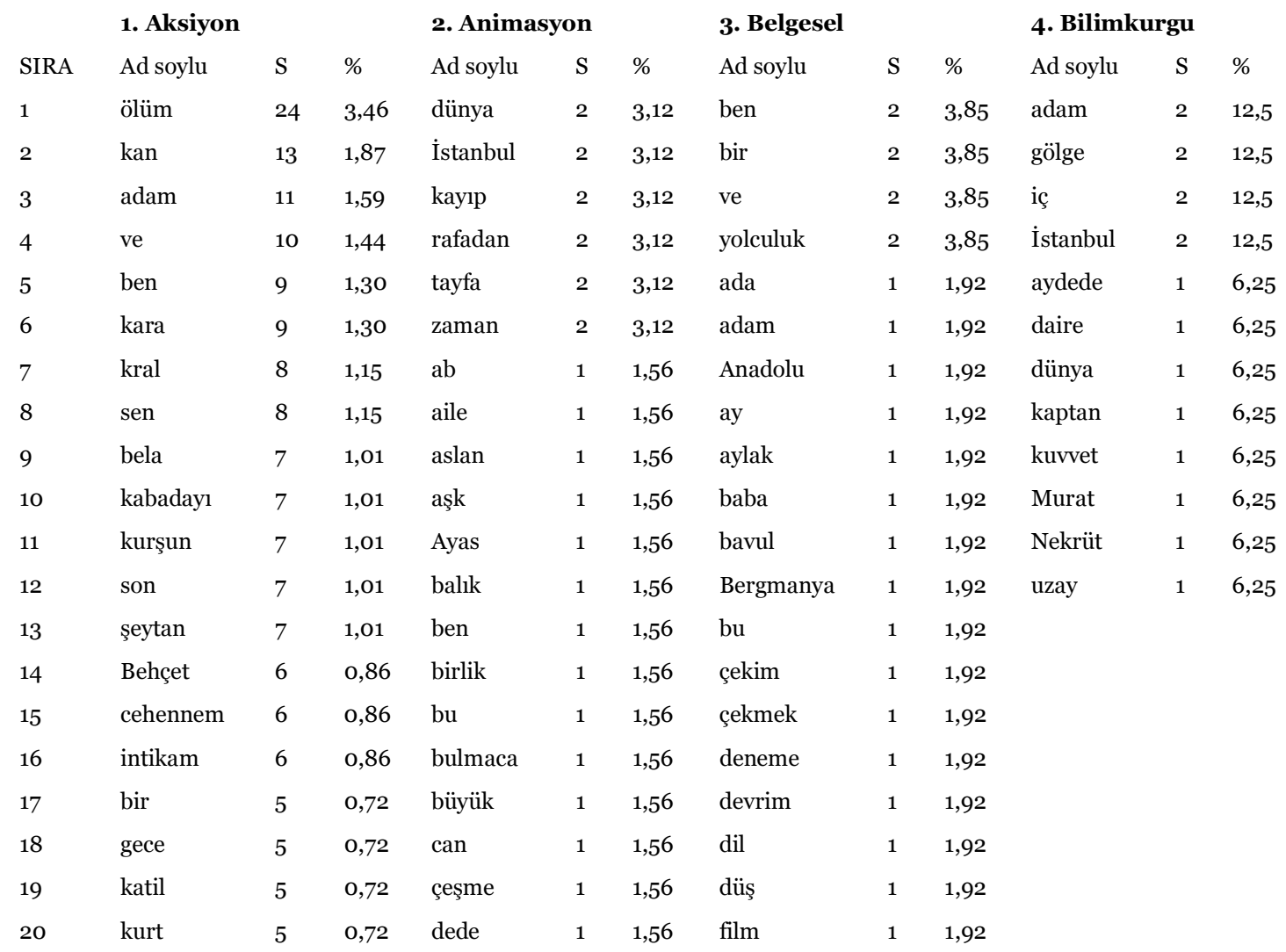

\footnotetext{
RumeliDE Dil ve Edebiyat Araştırmaları Dergisi Osmanağa Mahallesi, Mürver Çiçeği Sokak, No:14/8 Kadıköy - İSTANBUL / TÜRKIYE 34714 e-posta: editor@rumelide.com Address

RumeliDE Journal of Language and Literature Studies Osmanağa Mahallesi, Mürver Çiçeği Sokak, No:14/8 Kadıköy - ISTANBUL / TURKEY 34714

e-mail: editor@rumelide.com, tel: +90 505 7958124, +90 2167730616 phone: +90 505 7958124, +90 2167730616
} 
Türk film adlarına derlem tabanlı bir bakış / F. Bozkurt (93-127. s.)

5. Döküdrama

$\begin{array}{lll}\text { Ad soylu } & \text { S } & \% \\ \text { Anadolu } & 1 & 25 \\ \text { evliya } & 1 & 25 \\ \text { hanım } & 1 & 25 \\ \text { Latife } & 1 & 25\end{array}$

\section{Dram}

Ad soylu

bir

aşk

ben

kadın

ve

sen

kız

kara

gece

yol

hayat

dünya

son

kader

gün

acl

adam

çocuk

günah

iki

\section{Erotik}

Ad soylu

kiz

kadın

çlgın

aşk

bir

bela

gece

günah

seks

tatlı

0,61

0,59

0,56

0,56

0,54

0,52

0,51

0,51

0,49

0,46

0,46

0,46 dam

\section{Fantastik}

$\begin{array}{lll}\text { Ad soylu } & \mathrm{S} & \% \\ \text { adam } & 7 & 2,8 \\ \text { Kilink } & 6 & 2,4 \\ \text { ve } & 6 & 2,4 \\ \text { İstanbul } & 5 & 2 \\ \text { kız } & 5 & 2 \\ \text { süper } & 5 & 2 \\ \text { üç } & 5 & 2 \\ \text { intikam } & 4 & 1,6 \\ \text { kara } & 4 & 1,6 \\ \text { karşı } & 4 & 1,6 \\ \text { Süpermen } & 4 & 1,6 \\ \text { Zorro } & 4 & 1,6 \\ \text { casus } & 3 & 1,2 \\ \text { demir } & 3 & 1,2 \\ \text { dev } & 3 & 1,2 \\ \text { dişi } & 3 & 1,2 \\ \text { hafiye } & 3 & 1,2 \\ \text { kadın } & 3 & 1,2 \\ \text { şeytan } & 3 & 1,2 \\ \text { Tarkan } & 3 & 1,2\end{array}$

Adres

RumeliDE Dil ve Edebiyat Araştırmaları Dergisi Osmanağa Mahallesi, Mürver Çiçeği Sokak, No:14/8 Kadıköy - İSTANBUL / TÜRKIYE 34714 e-posta: editor@rumelide.com tel: +90 $5057958124,+902167730616$
Address

RumeliDE Journal of Language and Literature Studies Osmanağa Mahallesi, Mürver Çiçeği Sokak, No:14/8 Kadıköy - ISTANBUL / TURKEY 34714

e-mail: editor@rumelide.com,

phone: +90 $5057958124,+902167730616$ 


\section{Gerilim}

\begin{tabular}{|c|c|c|c|c|}
\hline SIRA & Ad soylu & $\mathrm{S}$ & $\%$ & Ad soylu \\
\hline 1 & dünya & 3 & 3,26 & $\mathrm{klz}$ \\
\hline 2 & çığlık & 2 & 2,17 & ben \\
\hline 3 & göz & 2 & 2,17 & bir \\
\hline 4 & İstanbul & 2 & 2,17 & aşk \\
\hline 5 & ne & 2 & 2,17 & ile \\
\hline 6 & sen & 2 & 2,17 & baba \\
\hline 7 & ya & 2 & 2,17 & ne \\
\hline 8 & anatomi & 1 & 1,09 & kadın \\
\hline 9 & ara & 1 & 1,09 & biz \\
\hline 10 & araf & 1 & 1,09 & deli \\
\hline 11 & asansör & 1 & 1,09 & sen \\
\hline 12 & asimetrik & 1 & 1,09 & var \\
\hline 13 & aşk & 1 & 1,09 & kral \\
\hline 14 & av & 1 & 1,09 & Şaban \\
\hline 15 & avcl & 1 & 1,09 & iş \\
\hline 16 & ayet & 1 & 1,09 & ve \\
\hline 17 & bar & 1 & 1,09 & tatlı \\
\hline 18 & bayrak & 1 & 1,09 & güzel \\
\hline 19 & bedel & 1 & 1,09 & $\mathrm{bu}$ \\
\hline 20 & benzersiz & 1 & 1,09 & İbo \\
\hline
\end{tabular}

\section{Korku}

$$
\text { Ad soylu }
$$

46

$46 \quad 1,39$

$45 \quad 1,36$

$42 \quad 1,27$

33

33

29

25

23

22

22

22

20

20

19

19
19

18

18

17

16

15

15
1,00

1,00

0,88

0,76 assk

0,70

0,67

0,67

0,61

$0,61 \quad$ ivc

0,58

$0,58 \quad$ el

0,55 iblis

0,55

0,52

0,49

0,45

0,45

üç dabbe

şeytan

siccin

araf

aşk

azap

azem

gece

harfli

deccal

$\begin{array}{ll}\text { cin } & 36\end{array}$

$\%$

12. Macera

Ad soylu S \%

$\begin{array}{lll}\text { büyü } \quad 6 & 1,69\end{array}$

ölüm

$32 \quad 1,79$

$6 \quad 1,69$

adam

31

kara

1,74

1,69

ve

1,29

1,41

ben

1,12

efe

$18 \quad 1,01$

$4 \quad 1,13$

$4 \quad 1,13$

$\begin{array}{lll}\text { kadın } & 16 \quad 0,90\end{array}$

0,90

kanun $\quad 16 \quad 0,90$

silah $\quad 16$

bir

0,90

$4 \quad 1,13$

$4 \quad 1,13$

$4 \quad 1,13$

intikam

15

0,84

kartal

15

0,84

$4 \quad 1,13$

kurtal

0,84

0,85

Murat $\quad 15$

0,84

0,85

kral

$14 \quad 0,78$

iblis $\quad 3$

0,85

kan

$13 \quad 0,73$

ifrit $\quad 3$

kanlı $\quad 3$

0,85

karşı

13

0,85 dağ

karanlık 3

0,85

son

aşk

kurşun
$12 \quad 0,67$

$12 \quad 0,67$

$11 \quad 0,62$

$11 \quad 0,62$
Adres

RumeliDE Dil ve Edebiyat Araştırmaları Dergisi Osmanağa Mahallesi, Mürver Çiçeği Sokak, No:14/8 Kadıköy - İSTANBUL / TÜRKIYE 34714 e-posta: editor@rumelide.com tel: +90 $5057958124,+902167730616$
Address

RumeliDE Journal of Language and Literature Studies Osmanağa Mahallesi, Mürver Çiçeği Sokak, No:14/8 Kadıköy - ISTANBUL / TURKEY 34714

e-mail: editor@rumelide.com,

phone: +90 505 7958124, +90 2167730616 


\begin{tabular}{|c|c|c|c|c|c|c|c|c|}
\hline 13. Melo & & & 14. Müz & & & 15. West & & \\
\hline Ad soylu & $\mathrm{S}$ & $\%$ & Ad soylu & $\mathrm{S}$ & $\%$ & Ad soylu & $\mathrm{S}$ & $\%$ \\
\hline aşk & 108 & 2,80 & beş & 1 & 14,29 & maskeli & 4 & 3,77 \\
\hline bir & 83 & 2,15 & bir & 1 & 14,29 & amigo & 3 & 2,83 \\
\hline kiz & 80 & 2,08 & dam & 1 & 14,29 & beş & 3 & 2,83 \\
\hline kadın & 77 & 2,00 & güzel & 1 & 14,29 & hey & 3 & 2,83 \\
\hline ben & 57 & 1,48 & kemancı & 1 & 14,29 & kan & 3 & 2,83 \\
\hline sen & 43 & 1,12 & $\mathrm{kız}$ & 1 & 14,29 & silah & 3 & 2,83 \\
\hline kader & 42 & 1,09 & köy & 1 & 14,29 & ve & 3 & 2,83 \\
\hline acı & 35 & 0,91 & & & & adam & 2 & 1,89 \\
\hline ile & 30 & 0,78 & & & & batı & 2 & 1,89 \\
\hline hayat & 28 & 0,73 & & & & belalı & 2 & 1,89 \\
\hline ölüm & 26 & 0,68 & & & & çeko & 2 & 1,89 \\
\hline gelin & 24 & 0,62 & & & & dönüş & 2 & 1,89 \\
\hline gönül & 24 & 0,62 & & & & haydut & 2 & 1,89 \\
\hline günah & 23 & 0,60 & & & & karşı & 2 & 1,89 \\
\hline son & 23 & 0,60 & & & & kin & 2 & 1,89 \\
\hline ve & 23 & 0,60 & & & & kit & 2 & 1,89 \\
\hline güzel & 22 & 0,57 & & & & kovboy & 2 & 1,89 \\
\hline sokak & 22 & 0,57 & & & & mezar & 2 & 1,89 \\
\hline gün & 21 & 0,55 & & & & ölüm & 2 & 1,89 \\
\hline kanlı & 21 & 0,55 & & & & red & 2 & 1,89 \\
\hline
\end{tabular}

Tablo 17: Türlere göre ad sıklı̆̆ı

Tablo 17.de film türlerine göre en sık kullanılan 20 ad soylu sözcük (ad, önad, adıl, belirteç, ilgeç, bağlaç, ünlem), S (sıklık sayısı) ve oranları gösterilmiştir.

Aksiyon türünde 694 ad sözcükbiçim vardır. Aksiyon türünde işlev sözcükleri çıkarıldığında aksiyon türünde ek sı kullanılan sözcükler "ölüm”, "kan”, "adam”, "kara”, "kral”, "kabadayı" biçimindedir. "kurşun", "katil”, "cehennem”, "intikam” gibi sözcükler bu türün doğası ile de ilişkilidir. Ayrıca listedeki "Behçet” sözcügü de seri film olması dolayısıyla en sık 20 sözcük listesine girmiştir. Öte yandan en sık kullanılan sözcüklerde ön plana çlkan özelliklerden biri ise eril sözcüklerin fazla oluşudur. Dikkat çeken önemli bir husus da ad soylu sözcüklerin eylem soylu sözcüklere göre listede fazla oluşudur. Zira bir bakıma içeriğinde, hareketin ön planda olduğu aksiyon türündeki film adlarında eylemlerin listede daha üst sıralarda yer alması beklentisi varken ad soylu sözcüklerin sayısı daha yüksektir.

Animasyon film türünde 64 ad sözcükbiçim vardır. Animasyon türünde en sık kullanılan sözcükler "dünya”, “İstanbul”, "kayıp”, "rafadan”, "tayfa”, “zaman”, “ab”, “aile”, "aslan” biçimindedir. Bu film türündeki sayının az olması sözcük sıklı̆̆ı ile ilgili yorumların geçerliliğini düşürmektedir. Bu türde "aslan”, "balık" gibi hayvan adlarının bulunması türün özelliğine uygun görünmektedir.

Belgesel film türünde 52 ad sözcükbiçim vardır. Belgesel türünde işlev sözcükleri dışında en sık kullanılan sözcükler "yolculuk”, "ada”, “adam”, “Anadolu” biçimindedir.

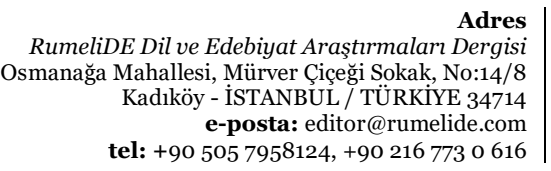

Adres

18 m

Address

RumeliDE Journal of Language and Literature Studies Osmanağa Mahallesi, Mürver Çiçeği Sokak, No:14/8

Kadıkö - ISTANBUL / TURKEY 34714

-mail: editor@rumelide.com,

phone: +90 5057958124 , +90 2167730616 
Bilimkurgu film türünde 16 ad sözcükbiçim vardır. Bilimkurgu film türünde işlev sözcükleri dışında en sık kullanılan sözcükler "adam”, "gölge”, "iç”, “İstanbul”, "aydede”, "daire” biçimindedir.

Döküdrama film türünde 4 ad sözcükbiçim vardır. Bu sözcükler şöyledir: "Anadolu", "evliya", "hanım", "Latife". Bu türde film sayısı ve dolasıyla sözcük sayısı da çok düşük miktarda olduğu için yorumlanabilecek veri miktarı da düşüktür.

Dram film türünde 6115 ad sözcükbiçim vardır. İşlev sözcükleri çıkarıldığında dram türünde en sık kullanılan sözcükler "aşk", "kadın”, "kız", "kara”, "gece”, “yol”, "hayat” biçimindedir. En sık kullanılan sözcüklerde ön plana çıkan özellik dişil sözcüklerin ve olumsuzluk çağrıştıran sözcüklerin fazla oluşudur.

Erotik film türünde 208 ad sözcükbiçim vardır. İşlev sözcükleri çıkarıldığında erotik film türünde en sık kullanılan sözcükler "kız”, "kadın”, “çılgın”, “aşk”, "bela”, "gece”, "günah” biçimindedir. En sık kullanılan sözcüklerde dişil sözcüklerin kullanılması ön plana çımaktadır.

Fantastik film türünde 250 ad sözcükbiçim vardır. Bu sözcükbiçimlerin 122 tanesi hapax legomanon olarak kullanılmıştır. Bu film türündeki adlarda dikkat çeken ilk husus en sık kullanılan 20 sözcük içerisinde işlev sözcüğü olarak "ve" sözcügünün kullanılmasıdır. Fantastik film türünde ad soylu olarak en sık kullanılan sözcükler "adam”, "Kilink”, "İstanbul”, "kız”, "süper”, “üç,", “intikam”, "kara”, "Süpermen" biçimindedir. Öteki film türlerine göre dikkat çeken başka bir husus ise en sik kullanılan ad soylu sözcükler olarak fantastik film adlarında "Kilink", "Zorro", "İstanbul" gibi özel adların fazla oluşudur.

Gerilim film türünde 92 ad sözcükbiçim vardır. İşlev sözcükleri çıkarıldığında gerilim film türünde en sık kullanılan sözcükler "dünya”, “çı̆̆llk”, "göz”, “İstanbul”, “anatomi”, “ara”, "araf”, "asansör” biçimindedir.

Komedi film türünde 3299 ad sözcükbiçim vardır. İşlev sözcükleri çıkarıldığında komedi film türünde en sı kullanılan sözcükler "kız", "aşk", "baba”, "kadın”, "deli”, "kral” biçimindedir. Bu sözcükler arasında dikkat çeken önemli bir husus komedi türünde sıralamadaki yer bakımından eril ve dişil sözcüklerin dengeli biçimde bulunmasıdır. Öte yandan Kemal Sunal ile özdeşleşen "Şaban" karakteri ve Feridun Karakaya’nın canlandırdığı "Cilalı İbo" karakterinin seri hâlinde filmlerinin olması bu özel ad özelliği taşıyan sözcüklerin sıklık listesinde üst sıralarda bulunmasını sağlamıştır.

Korku film türünde 355 ad sözcükbiçim vardır. Korku film türünde öteki türlere göre en çok dikkat çeken husus işlev sözcüklerinin tek oluşudur. Daha da ilginç bir durum ise işlev sözcüğü olarak Türkçe sözcüklerin değil Arapça bir tanımlık olan "el" sözcüğünün kullanılmasıdır. Korku film türünde en sık kullanılan sözcükler "cin”, "büyü”, “dabbe”, "şeytan”, "siccin”, “araf”, "aşk”, "azap” biçiminde, dinî çağrışımlarıyla ön plana çıkan sözcüklerdir. Bu sözcükler arasında diğerlerinden farklı olarak "aşk" sözcügünün kullanılması da dikkat çekmektedir.

Macera film türünde 1786 ad sözcükbiçim vardır. İşlev sözcükleri çıkarıldığında bu türde ön plana çıan sözcükler "ölüm”, "adam”, "kara”, “efe”, "kadın”, "kanun”, "silah”, “intikam” biçimindedir. Ayrıca Kara Murat serisinden dolayı "Murat" özel adı ve "kara" sıfatı sıklıkta üst sıralarda yer almıştır. Bir hayvan adı olan "kartal" sözcüğünün de sıklıkta üst sıralarda bulunması dikkat çekicidir.

Melodram film türünde 3852 ad sözcükbiçim vardır. İşlev sözcükleri çıkarıldığında bu türde ön plana çıkan sözcükler "aşk”, "kız”, "kadın”, "kader”, “acı”, "hayat”, “ölüm”, "gelin” biçimindedir. En sık

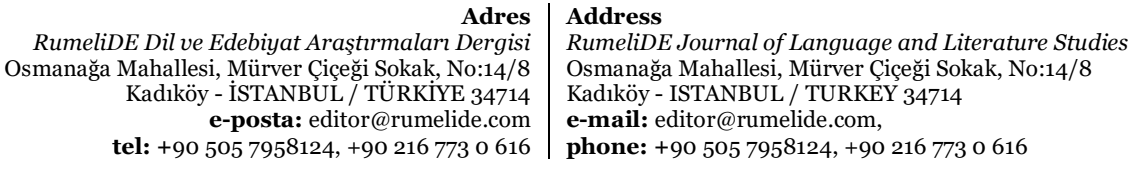


kullanılan sözcüklerde dişil sözcüklerin kullanılması ön plana çıkmaktadır. Ayrıca hayat ve ölüm gibi karşıtlıkların yakın oranda görülmesi de ilginç bir durumdur.

Western film türünde 106 ad sözcükbiçim vardır. İşlev sözcükleri çıkarıldı̆̆ında bu türde ön plana çlkan sözcükler "maskeli”, "amigo", "beş”, "hey”, "kan”, "silah”, "adam”, "batı” biçimindedir. Bu sözcükler türün özelliklerini yansıtmaktadır.

\section{Aksiyon}

$\begin{array}{llll}\text { SIRA } & \text { Eylem } & \text { S } & \text { \% } \\ 1 & \text { vur- } & 11 & 9,65 \\ 2 & \text { öldür- } & 8 & 7,02 \\ 3 & \text { gel- } & 7 & 6,14 \\ 4 & \text { ol- } & 6 & 5,26 \\ 5 & \text { sev- } & 5 & 4,39 \\ 6 & \text { kaç- } & 4 & 3,51 \\ 7 & \text { affet- } & 3 & 2,63 \\ 8 & \text { bastır- } & 3 & 2,63 \\ 9 & \text { çek- } & 3 & 2,63 \\ 10 & \text { de- } & 3 & 2,63 \\ 11 & \text { et- } & 3 & 2,63 \\ 12 & \text { öl- } & 3 & 2,63 \\ 13 & \text { öp- } & 3 & 2,63 \\ 14 & \text { saç- } & 3 & 2,63 \\ 15 & \text { asıl- } & 2 & 1,75 \\ 16 & \text { bekle- } & 2 & 1,75 \\ 17 & \text { git- } & 2 & 1,75 \\ 18 & \text { kahret- } & 2 & 1,75 \\ 19 & \text { yaşa- } & 2 & 1,75 \\ 20 & \text { affedil- } & 1 & 0,88 \\ & & & \end{array}$

\section{Animasyon 3. Belgesel}

Eylem S \%

bat- $\quad 1 \quad 50$

gel- $\quad 1 \quad 50$

\section{Eylem S}

yap-

1

\section{Bilimkurgu}

$\begin{array}{lll}\text { Eylem } & \text { S } & \text { \% } \\ \text { git- } & 1 & 25 \\ \text { görün- } & 1 & 25 \\ \text { kurtar- } & 1 & 25 \\ \text { uç- } & 1 & 25\end{array}$

Adres

RumeliDE Dil ve Edebiyat Araştırmaları Dergisi Osmanağa Mahallesi, Mürver Çiçeği Sokak, No:14/8 Kadıköy - İSTANBUL / TÜRKIYE 34714 e-posta: editor@rumelide.com tel: +90 $5057958124,+902167730616$
Address

RumeliDE Journal of Language and Literature Studies Osmanağa Mahallesi, Mürver Çiçeği Sokak, No:14/8 Kadıköy - ISTANBUL / TURKEY 34714

e-mail: editor@rumelide.com

phone: +90 5057958124, +90 2167730616 


\section{5•3.2.2. Film türlerine göre eylemlerin sıklıkları}

\begin{tabular}{|c|c|c|c|c|c|c|c|c|c|c|c|}
\hline \multicolumn{3}{|c|}{ 5. Döküdrama } & \multicolumn{3}{|c|}{ 6. Dram } & \multicolumn{3}{|c|}{ 7. Erotik } & \multicolumn{3}{|c|}{ 8. Fantastik } \\
\hline Eylem & $\mathrm{S}$ & $\%$ & Eylem & $\mathrm{S}$ & $\%$ & Eylem & $\mathrm{S}$ & $\%$ & Eylem & $\mathrm{S}$ & $\%$ \\
\hline \multirow[t]{20}{*}{ - } & - & & sev- & 51 & 8,66 & çık- & 3 & 9,68 & kır- & 2 & 12,50 \\
\hline & & & ol- & 40 & 6,79 & sev- & 3 & 9,68 & öldür- & 2 & 12,50 \\
\hline & & & öl- & 30 & 5,09 & uç- & 3 & 9,68 & saç- & 2 & 12,50 \\
\hline & & & gel- & 22 & 3,74 & de- & 2 & 6,45 & sev- & 2 & 12,50 \\
\hline & & & ağla- & 20 & 3,40 & doy- & 2 & 6,45 & anlat- & 1 & 6,25 \\
\hline & & & yaşa- & 19 & 3,23 & ol- & 2 & 6,45 & çarpış- & 1 & 6,25 \\
\hline & & & kal- & 17 & 2,89 & affet- & 1 & 3,23 & dön- & 1 & 6,25 \\
\hline & & & git- & 15 & 2,55 & bak- & 1 & 3,23 & gel- & 1 & 6,25 \\
\hline & & & bit- & 13 & 2,21 & bastır- & 1 & 3,23 & konuş- & 1 & 6,25 \\
\hline & & & bekle- & 11 & 1,87 & bekle- & 1 & 3,23 & ol- & 1 & 6,25 \\
\hline & & & gör- & 11 & 1,87 & bil- & 1 & 3,23 & uç- & 1 & 6,25 \\
\hline & & & iste- & 10 & 1,70 & boz- & 1 & 3,23 & yll- & 1 & 6,25 \\
\hline & & & vur- & 10 & 1,70 & dinle- & 1 & 3,23 & & & \\
\hline & & & doğ- & 9 & 1,53 & dur- & 1 & 3,23 & & & \\
\hline & & & dön- & 9 & 1,53 & düş- & 1 & 3,23 & & & \\
\hline & & & düş- & 9 & 1,53 & konuş- & 1 & 3,23 & & & \\
\hline & & & öldür- & 9 & 1,53 & oyna- & 1 & 3,23 & & & \\
\hline & & & unut- & 9 & 1,53 & öldür- & 1 & 3,23 & & & \\
\hline & & & de- & 8 & 1,36 & vur- & 1 & 3,23 & & & \\
\hline & & & söyle- & 6 & 1,02 & vuruş- & 1 & 3,23 & & & \\
\hline
\end{tabular}




\begin{tabular}{|c|c|c|c|c|c|c|c|c|c|c|c|c|}
\hline & 9. Gerilim & & & 10. Kor & & & 11. Korl & & & 12. Macera & & \\
\hline SIRA & Eylem & $\mathbf{S}$ & $\%$ & Eylem & $\mathbf{S}$ & $\%$ & Eylem & $\mathbf{S}$ & $\%$ & Eylem & $\mathbf{S}$ & $\%$ \\
\hline 1 & gel- & 1 & 25 & ol- & 31 & 9,17 & gel- & 3,00 & 23,08 & gel- & 18 & 10,98 \\
\hline 2 & git- & 1 & 25 & gel- & 17 & 5,03 & çağır- & 1,00 & 7,69 & öl- & 7 & 4,27 \\
\hline 3 & gör- & 1 & 25 & de- & 14 & 4,14 & çağrıl- & 1,00 & 7,69 & de- & 6 & 3,66 \\
\hline 4 & ol- & 1 & 25 & sev- & 14 & 4,14 & dön- & 1,00 & 7,69 & bak- & 4 & 2,44 \\
\hline 5 & & & & gül- & 11 & 3,25 & görün- & 1,00 & 7,69 & buluş- & 4 & 2,44 \\
\hline 6 & & & & git- & 10 & 2,96 & konuş- & 1,00 & 7,69 & sev- & 4 & 2,44 \\
\hline 7 & & & & al- & 7 & 2,07 & oku- & 1,00 & 7,69 & vur- & 4 & 2,44 \\
\hline 8 & & & & bul- & 7 & 2,07 & ol- & 1,00 & 7,69 & affet- & 3 & 1,83 \\
\hline 9 & & & & dön- & 7 & 2,07 & öl- & 1,00 & 7,69 & ağla- & 3 & 1,83 \\
\hline 10 & & & & çlk- & 6 & 1,78 & saklan- & 1,00 & 7,69 & doğ- & 3 & 1,83 \\
\hline 11 & & & & kal- & 6 & 1,78 & tat- & 1,00 & 7,69 & iste- & 3 & 1,83 \\
\hline 12 & & & & ver- & 6 & 1,78 & & & & öldür- & 3 & 1,83 \\
\hline 13 & & & & yap- & 6 & 1,78 & & & & seviş- & 3 & 1,83 \\
\hline 14 & & & & et- & 5 & 1,48 & & & & ak- & 2 & 1,22 \\
\hline 15 & & & & aldat- & 4 & 1,18 & & & & bombala- & 2 & 1,22 \\
\hline 16 & & & & bak- & 4 & 1,18 & & & & bul- & 2 & 1,22 \\
\hline 17 & & & & çal- & 4 & 1,18 & & & & çalkala- & 2 & 1,22 \\
\hline 18 & & & & duy- & 4 & 1,18 & & & & dövüş- & 2 & 1,22 \\
\hline 19 & & & & evlen- & 4 & 1,18 & & & & gül- & 2 & 1,22 \\
\hline 20 & & & & iste- & 4 & 1,18 & & & & kaçıl- & 2 & 1,22 \\
\hline
\end{tabular}

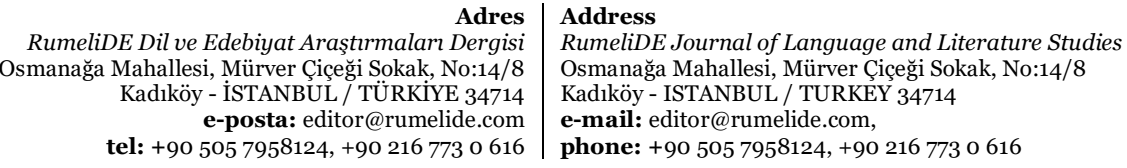


122 / RumeliDE Journal of Language and Literature Studies 2021.24 (September)

A corpus-based view of Turkish movie names / F. Bozkurt (pp. 93-127)

\begin{tabular}{|c|c|c|c|c|c|c|c|c|}
\hline \multicolumn{3}{|c|}{ 13. Melodram } & \multicolumn{3}{|c|}{ 14. Müzikal } & \multicolumn{3}{|c|}{ 15. Western } \\
\hline Eylem & $\mathrm{S}$ & $\%$ & Eylem & $\mathrm{S}$ & $\%$ & Eylem & $\mathrm{S}$ & $\%$ \\
\hline sev- & 46 & 10,25 & vurul- & 1 & 100,00 & ac1- & 1 & 14,29 \\
\hline ol- & 29 & 6,46 & & & & bil- & 1 & 14,29 \\
\hline ağla- & 24 & 5,35 & & & & gel- & 1 & 14,29 \\
\hline öl- & 20 & 4,45 & & & & konuş- & 1 & 14,29 \\
\hline gel- & 13 & 2,90 & & & & sev- & 1 & 14,29 \\
\hline öldür- & 11 & 2,45 & & & & sıçra- & 1 & 14,29 \\
\hline vur- & 10 & 2,23 & & & & vur- & 1 & 14,29 \\
\hline yaşa- & 10 & 2,23 & & & & & & \\
\hline bit- & 9 & 2,00 & & & & & & \\
\hline de- & 8 & 1,78 & & & & & & \\
\hline git- & 8 & 1,78 & & & & & & \\
\hline doğ- & 7 & 1,56 & & & & & & \\
\hline unut- & 7 & 1,56 & & & & & & \\
\hline ayrıl- & 6 & 1,34 & & & & & & \\
\hline düş- & 6 & 1,34 & & & & & & \\
\hline affet- & 5 & 1,11 & & & & & & \\
\hline al- & 5 & 1,11 & & & & & & \\
\hline ara- & 5 & 1,11 & & & & & & \\
\hline ayır- & 5 & 1,11 & & & & & & \\
\hline bekle- & 5 & 1,11 & & & & & & \\
\hline
\end{tabular}

Tablo 18: Türlere göre eylem sıklı̆̆ı Osmanağa Mahallesi, Mürver Çiçeği Sokak, No:14/8 Kadıköy - İSTANBUL / TÜRKIYE 34714 e-posta: editor@rumelide.com tel: +90 $5057958124,+902167730616$
Address

RumeliDE Journal of Language and Literature Studies Osmanağa Mahallesi, Mürver Çiçeği Sokak, No:14/8 Kadıköy - ISTANBUL / TURKEY 34714

e-mail: editor@rumelide.com,

phone: +90 $5057958124,+902167730616$ 
Tablo 18.de film türlerine göre en sık kullanılan 20 eylem, S (sıklık sayısı) ve oranları gösterilmiştir.

Aksiyon türündeki filmlerde 105 eylem kullanılmıştır. En sık kullanılan eylemler "vur-“, "öldür-“, "kaç-“ türün çağrışımına uygun biçimde hareket bildiren eylemler sık olarak kullanılmıştır. "sev-“, "affet-" ve "öp-“ gibi duygulara yönelik eylemlerinin bu türde sık kullanılması ise ilginçtir.

Animasyon türünde toplam 66 sözcük vardır, sadece iki eylem kullanılmıştır. Bu türde film sayısı az olmakla birlikte eylem sayısının bu kadar düşük olması ilginçtir.

Belgesel türünde toplam 53 sözcük vardır, sadece bir eylem kullanılmıştır. Bu türde film sayısının çok yüksek olmamasına rağmen bu kadar az eylemin kullanılması oldukça ilginçtir.

Bilimkurgu türünde toplam 20 sözcük vardır, dört eylem kullanılmıştır. Bilimkurgu türü ile animasyon türü karşılaştırıldığında animasyon türündeki sözcük sayısı bilimkurgu türünün üç katı olmasına rağmen bilimkurgu türündeki eylem sayısı animasyonunkinin üç katıdır.

Döküdrama türünde toplam 4 sözcük vardır. Hiç eylem kullanılmamıştır.

Dram türündeki filmlerde 589 eylem kullanılmıştır. Dram türündeki filmlerde "sev-“, "öl-“, "ağla-“ eylemlerinin en sık kullanılan eylemler olması türün tipik özelliğini yansıtmaktadır. Duygu eylemlerinin sık kullanılması olağandır. "ol-“ eyleminin sık kullanılmasının nedeni ise bu eylemin yardımcı eylem olarak kullanılmasıdır.

Erotik türdeki filmlerde 31 eylem kullanılmıştır. Erotik türdeki filmlerde "çlk-“6, "sev-“, "uç-“, "de-“, "doy-“, "ol-“, "affet-“, "bak-“, "bastır-“ eylemleri en sık biçimde kullanılmaktadır.

Fantastik türdeki filmlerde 16 eylem kullanılmıştır. Fantastik türdeki filmlerde "kır-“, "öldür-“, "saç”, ”sev-“, "anlat-“, "çarpış-“ eylemleri en sık bicimde kullanılmaktadır. Türün özellikleri düşünüldüğünde eylemlerle türün özellikleri arasında tam anlamıyla ilişki yoktur. Bunun gerekçesi olarak eylem sayılarının düşüklüğünü göstermek mümkündür.

Gerilim türündeki filmlerde toplam 96 sözcük vardır. 4 eylem kullanılmıştır. Toplam sözcük sayısına oranla bu türde çok az eylem kullanılmıştır. Zira animasyon, belgesel ve bilimkurgu türlerinde de sözcük sayısı az olmakla birlikte eylemler kullanılmıştır ancak oranı gerilim türüne göre daha yüksektir.

Komedi türündeki filmlerde toplam 338 eylem kullanılmıştır. Komedi türündeki filmlerde en sık kullanılan eylemler "ol-“, "gel-“, "de-“, "sev-“, "gül-“, "git-“, "al-“, "bul-“ biçimindedir. Bu eylemlerden "gül-“ eylemi türün tipik özelliğini yansıtmaktadır.

Korku türündeki filmlerde toplam 13 eylem kullanılmıştır. Korku türündeki filmlerde en sık kullanılan eylemler "gel-“, "çağır-“, "çağrıl-“, "dön-“, "görün-“ biçimindedir. Bu eylemlerin özellikle farklı bir âlemden bu dünyaya intikaline ilişkin dinî çağrışım olması dikkat çekicidir.

Macera türündeki filmlerde toplam 164 eylem kullanılmıştır. Macera türünde en sık kullanılan eylemler "gel-“, “öl-“, “de-“, "bak-“, "buluş-“, "sev-“, “vur-“, “affet-“, “ağla-“, “doğ-“, "iste-“, "öldür-“

6 Buradaki "çık-“ eylemi “doğmak” anlamında kullanılmıştır.

$$
\begin{aligned}
& \text { Adres } \mid \begin{array}{ll}
\text { Address } \\
\text { Adres }
\end{array} \\
& \text { RumeliDE Dil ve Edebiyat Araştırmaları Dergisi } \quad \text { RumeliDE Journal of Language and Literature Studies } \\
& \text { Osmanağa Mahallesi, Mürver Çiçeği Sokak, No:14/8 } \text { Osmanağa Mahallesi, Mürver Çiçeği Sokak, No:14/8 } \\
& \text { Kadıköy - İSTANBUL / TÜRKIYE } 34714 \text { Kadıöy - ISTANBUL / TURKEY } 34714 \\
& \text { e-posta: editor@rumelide.com } \quad \text { e-mail: editor@rumelide.com, } \\
& \text { tel: +90 505 7958124, +90 } 2167730616 \text { phone: +90 505 7958124, +90 } 2167730616
\end{aligned}
$$


biçimindedir. Bu eylemlerden "öl-“, "vur-“, "öldür-“ film türünün özelliklerini yansıtmaktadır ancak "sev-", "affet-" gibi duygu eylemlerinin burada bulunması ilginçtir.

Melodram türündeki filmlerde toplam 449 eylem kullanılmıştır. Melodram türündeki filmlerde en sık kullanılan eylemler "sev-“, “ol-“, “ağla-“, “öl-“, "gel-“, “öldür-“, "vur-“, “yaşa-“, "bit-“, "de-“ biçimindedir. Bu eylemlerden "sev-“, "ağla-“, "öl-“ türün tipik özelliklerini yansıtmaktadır.

Müzikal türünde toplam 8 sözcük vardır, sadece bir eylem kullanılmıştır, o eylem ise âşı olmak anlamındaki "vurul-“" eylemidir.

Western türünde toplam 113 sözcük vardır, sadece 7 eylem kullanılmıştır. "sıçra-“ ve özellikle "vur-“ eylemi bu türün özelliğini yansıtmaktadır.

\section{Sonuç}

Türk sinemasındaki film adlarının ele alındığı bu çalışmanın veri tabanını toplam 7923 film adı oluşturmuştur. Çalışmanın çıkış noktasını Türk film adlarının sözcüksel yoğunluğu ve türlere göre değişkenliği ve benzerliği oluşturmuştur. Çalışmada yöntem olarak derlem tabanlı bir yaklaşım tercih edilmiştir. Bulgular bölümünde ele alınan ölçütlere göre farklılık ya da benzerlik gösteren hususlar aktarılmıştır.

Çalışmada yöntem olarak derlem tabanlı bir yaklaşım tercih edilmiştir. Çalışma kapsamında Türk Film Adları Derlemi adında küçük bir derlem oluşturulmuştur. Bulgular bölümünde ele alınan ölçütlere göre farklılık ya da benzerlik gösteren hususlar aktarılmıştır.

Sözcük sayıları bakımından Türk film adlarının türlere göre farklılıklar gösterdiği sonucuna ulaşılmıştır. Ayrıca film adlarının çoğu türde oransal olarak baskın biçimde üç sözcükten oluştuğu görülmüştür.

Sözcük uzunluğu bakımından tüm filmlerin ortalaması 2.35 sözcüktür. Sözcük uzunluğu açısından da türlere göre farklılıklar vardır. Korku ve gerilim filmleri öteki türlere göre daha az sözcük içermektedir.

Genel sözcük sıklığında ilk olarak ad soylu sözcüklerin sıklığı incelendiğinde ilk dikkat çeken durum genel dil derlemine göre daha az işlev sözcüğü olmasıdır. Ayrıca cinsiyet ve olumsuzluk çağrıştıran sözcükler sıklıkta üst basamaklardadır. Ad soylu sözcükler genel dil derlemi ile karşılaştırıldığında bu listelerin büyük oranda farklılıkları olduğu ortaya çıkmıştır. Genel sözcük sıklı̆̆ında eylemlerin sıklı̆̆ı incelendiğinde ise duygu eylemlerinin sıklık listesinde üst sıralarda olduğu görülmüştür.

Tüm sözcüklerin sıklıkları ad soylular ve eylemler birlikte ele alınarak karşılaştıııldığında yüksek sıklık listesinde ad soylu sözcüklerin eylemlere göre fazla olduğu görülmüştür.

Film türlerine göre sözcük sıklıklarında ad soylu sözcükleri genellikle türün özelliklerini çağrıştıran bir nitelikte olduğu görülmüştür. Film türlerine göre eylemlerin sıklı̆̆ı yine türlerin özelliklerine uygun biçimde gözükmektedir. Örneğin dram türünde duygu eylemleri ön planda iken aksiyon türünde hareket eylemleri üst siralardadır.

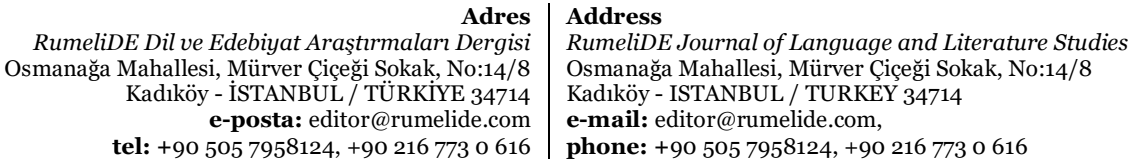




\section{Kuramsal çıarımlar}

Sanatın bir türü olup Türk halkına eğlenme aracı olarak sunulan Türk filmlerinin önemli bir parçası olan film adları bir dil verisi olarak Türk halkının kültürel yapısına ilişkin bilgiler sunmaktadır. Şüphesiz ki filmin senaryosunu yazarken adını da veren kişiler bu eylemi gerçekleştirirken Türk halkına ait dilsel çağrışım dünyasını da gözetmektedir. Dolayısıyla Türkçe olarak üretilmiş film adları Türk halkına sunduğu çağrışım ve duygu dünyasına ait izler taşımaktadır. Gülmeyi, korkmayı, sevmeyi, üzülmeyi, şaşırmayı içeren komedi, korku, melodram, fantastik gibi film türleri bir yönden duygu dünyasına ait izler taşımaktadır. Bu çalışmada dil verisi olarak kullanılan film adları üzerinden türlere göre dil değişkenlerini ortaya koymaktadır. Aslında adbilim çalışmalarının birçoğu ad ver(il)me özelliklerinden yola çıkarak toplumun duyuş, düşünüş ve olaylara yaklaşım özelliklerini ele almaktadır.

\section{Kisıtlılıklar ve gelecek çalışmalar}

Türk film adlarındaki durumu tam olarak betimleyebilmek için bir örneklem üzerinde çalışmak yerine tüm evren üzerinde çalışmak tercih edilmiştir. Bu durum ise özellikle sözcük sıklığı, sözcük uzunluğu vb. durumların betimlenmesinde bir avantaj sağlarken makale düzeyinde olacak bu çalışmada tüm verilerin raporlanmasını imkânsız kılmıştır. Zira veri tabanı bu çalışmada sunulandan daha fazla içeriğe sahiptir. Bu veri tabanında uygun işaretleme ile anlambilim, kökenbilim, biçimbilgisi sesbilgisi olmak üzere dilbilgisinin alt çalışma alanları bakımından çeşitli özellikleri incelemek ve betimlemek mümkün olacaktır.

$\mathrm{Bu}$ durumdan hareketle TFAD'daki verilerin işaretleme açısından zenginleştirilmesi ve film adlarının başka yönlerinin de ele alınması gerektiği düşünülmüştür. Böyle bir çalışmanın ise projelendirme ile mümkün olacă̆ı öngörülmüş ve projeye başlanmıştır. Böylece birkaç makale, belki kitap boyutunda raporlanacak bilgiler çalışmanın başında da bahsedildiği gibi insanın sanatsal yaratıcılık yeteneğinin bir dışavurumu olan film adlarının Türkçedeki görünümünü daha kapsamlı olarak betimlemek açısından önem arz etmektedir. Zira İngilizce veya başka diller için film adlarıyla ilgili yapılmış çalışmaları, dünyadaki diğer örneklerinin ardında kalmayıp yüz yaşını geçen Türk sineması da hak etmektedir. Böylece Türkçenin bu husustaki dil ve anlatım özellikleri de ortaya konulmuş olacaktır.

\section{Kisaltmalar}

TFAD: Türk Film Adları Derlemi

\section{Kaynakça}

Aksan, Y., Aksan, M., Mersinli, Ü. ve Demirhan, U. U. (2016). A frequency dictionary of Turkish, Londra: Routledge.

Alvarez-Altman, G., Burelbach, F. M., Oyarzun, L. A. ve Bowman, W. P. (1987). Names in literature: essays from literary onomastics Studies. Lanham: University Press of America.

Alvarez-Altman, Grace (1981). "Literary onomastics typology: Analytic guidelines to literary onomastics studies. Literary Onomastics Studies. 8, 220-230.

Anthony, L. (2020). AntConc (Version 3.5.9) [Bilgisayar Yazılı] Tokyo, Japan: Waseda University. Available from https://www.laurenceanthony.net/software

Bernstein, J. H. (2007). New York placenames in film titles. Names: A Journal of Onomastics. 55:2, 139-166.

Bulut, M. (2020). Atsız’n "Bozkurtlar” romanındaki kişi adları üzerine. Uluslararası Beşeri Bilimler Ve Ĕ̆itim Dergisi (IJHE). C.6, S. 13, $319-351$.

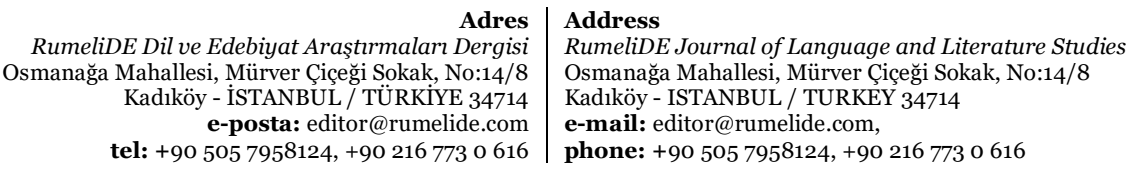


Coşkun, A. O. (1981). Kut kelimesi ve Kutadgu Bilig adı. Milli Eğitim ve Kültür. 3/12, 58-64.

Demir, K. (2019). Ahmet Hamdi Tanpınar'ın romanlarında özel adlar (Yayımlanmamış yüksek lisans tezi). Pamukkale Üniversitesi Sosyal Bilimler Enstitüsü, Denizli.

Dengler, R. (1975). The language of film titles. Journal of Communication. C. 25, 51-60.

Evans, J. C. (1967). Some current American pencil names. Names: A Journal of Onomastics. 15, 32-38.

Evren, B. (1995). Sinema tarihimizin bilinmeyen ilk filmleri. Antrakt. S. 45, 48-49.

Frey, R. S., Piernot, C. A., Elhardt, D. G., ve Elhardt, D. G. (1981). An analysis of Riesman's historical thesis through American film titles. The Journal of Social Psychology. 113(1), 57-64.

Gülensoy, T. (1987). Kaşgarlı Mahmud'un eserinin adı üzerine. Frrat Üniversitesi Sosyal Bilimler Dergisi. I (2), 151-154.

Karademir, F. (2009). Dilbilgisel görünümleri açısından çocuk kitap adları. Uluslararası Sosyal Araşttrmalar Dergisi. 2/9, 216-229.

Karademir, F. (2010). Edebî özellikleri açısından çocuk kitap adları. Dumlupınar Üniversitesi Sosyal Bilimler Dergisi. S. 27, 1-27.

Karamanlığlu, A. F. (1970). Kutadgu Bilig’in diline ve adına dair. Türk Kültürü. C. IX/98, 59-63.

Kayasandık, A. (2019). The bibliography essay of Turkish personal names. Journal of Strategic Research in Social Science. 5(1), 57-90.

Keleş, D. (1996). Türk adbilimi bibliyografyası (Yayımlanmamış yüksek lisans tezi). Hacettepe Üniversitesi Sosyal Bilimler Enstitüsü, Ankara.

Kızanbek, S. (2019). Türk romanında başlıklar (Yayımlanmamış yüksek lisans tezi). Sakarya Üniversitesi Sosyal Bilimler Enstitüsü, Sakarya.

Kibar, O. (2005). Türk kültüründe ad verme kişi adları üzerine bir tasnif denemesi. Ankara: Akçă̆.

Nicolaisen, W. F., (2008). On names in literature. Nomina. 31, 89-98.

Nuessel, F. (2010). A note on names for energy drink brands and products. Names: A Journal of Onomastics. 58(2), 102-110.

Nuessel, F. (2014). A note on the brand names for 'bath salts'. Names: A Journal of Onomastics 62: 4956.

Nuessel, F. (2016). A note on selected brand names of E-Cigarettes. Names: A Journal of Onomastics. 64: 41-49.

Orbay, O. N. (2019). Sözdizimi özellikleri bakımından öykü kitabı adları. Türük Uluslararası Dil, Edebiyat ve Halkbilimi Araştırmaları Dergisi. 18, 167-179.

Özer, S. (2015). Türkçede roman adlarının yapısal ve kavramsal analizi (Yayımlanmamış yüksek lisans tezi). Adana: Çukurova Üniversitesi Sosyal Bilimler Enstitüsü.

Özgüç, A. (1998). Türk filmleri sözlüğü. İstanbul: SESAM.

Özgüç, A. (2009). Türk Filmleri Sözlüğü 1917-2009. İstanbul: T. C. Kültür ve Turizm Bakanllğı ve SESAM.

Özgüç, A. (2012). Ansiklopedik Türk filmleri sözlüğü. İstanbul: Horizon International.

Rajec, E. M. (1987). A selected bibliography of Shakespeare and literary onomastics. Names:A Journal of Onomastics. 35(3-4), 224-231.

Sakaoğlu, S. (2001). Türk ad bilimi I (Giriş). Ankara: Türk Dil Kurumu Yayınları.

Smith, G. W. (2016). Theoretical foundations of literary onomastics. Carole Hough (Ed.), The Oxford handbook of names and naming içinde. 295-310. Oksford: Oxford University Press.

Şahin, İ. (2015). Adbilim (çerçeve, terim, yöntem ve sinıflandırmalarıyla). Ankara: Pegem Akademi Yayınları.

$$
\begin{array}{r|l}
\text { Adres } & \text { Address } \\
\text { RumeliDE Dil ve Edebiyat Araştırmaları Dergisi } & \text { RumeliDE Journal of Language and Literature Studies } \\
\text { Osmanağa Mahallesi, Mürver Çiçği Sokak, No:14/8 } & \text { Osmanağa Mahallesi, Mürver Çiçeği Sokak, No:14/8 } \\
\text { Kadıköy - İSTANBUL / TÜRKIYY 34714 } & \text { Kadıöy - ISTANBUL / TURKEY 34714 } \\
\text { e-posta: editor@rumelide.com } & \text { e-mail: editor@rumelide.com, } \\
\text { phone: +90 505 7958124, +90 } 2167730616
\end{array}
$$


Tarpley, F. (1985). Heaven and Hell, Paris and Texas: Placenames in film titles. Names: A Journal of Onomastics 33: 74-79.

\section{Elektronik kaynaklar}

Carole Hough, (2020) https://onomastics.co.uk/ (Erişim tarihi: 23.12.2020)

Türk Sineması Araştırmaları https://www.tsa.org.tr/tr/sayfa/sayfadetay/1/hakkimizda (Erişim tarihi: 10.10.2020)

Türk Dil Kurumu Güncel Türkçe Sözlük https://sozluk.gov.tr/ (Erişim tarihi: 11.12.2020)

Literary Onomastics Studies: https://digitalcommons.brockport.edu/los/about.html (Erişim tarihi: 12.12.2020)

Sinemalar https://www.sinemalar.com (Erişim tarihi: 2.10.2020)

RumeliDE Dil ve Edebiyat Araştırmaları Dergisi Osmanağa Mahallesi, Mürver Çiçeği Sokak, No:14/8 Kadıköy - ÍSTANBUL / TÜRKIYE 34714 e-posta: editor@rumelide.com tel: +90 $5057958124,+902167730616$
Address

RumeliDE Journal of Language and Literature Studies Osmanağa Mahallesi, Mürver Çiçeği Sokak, No:14/8

Kadıköy - ISTANBUL / TURKEY 34714

e-mail: editor@rumelide.com,

phone: +90 505 7958124, +90 2167730616 